\title{
REVOLUÇÃO TECNOLÓGICA, CRISE DA DEMOCRACIA E MUDANÇA CLIMÁTICA: LIMITES DO DIREITO NUM MUNDO EM TRANSFORMAÇÃO' ${ }^{1}$
}

LUÍS ROBERTO BARROSO²

RESUMO: O Direito é uma instituição universal, que tem pretensões de ubiquidade e completude. No entanto, em um mundo complexo, plural e volátil, seus limites e possibilidades são abalados pela velocidade, profundidade e extensão das transformações em curso, bem como pelos dilemas éticos que delas decorrem e pelas dificuldades de se formarem consensos no universo da política. O presente artigo traz uma reflexão sobre o modo como o Direito tem procurado lidar com algumas das principais aflições do nosso tempo, diante de demandas que incluem a necessidade de (i) manter a revolução tecnológica numa trilha ética e humanista, (ii) impedir que a democracia se perverta em aventuras populistas e autoritárias e (iii) evitar que as reações à mudança climática só venham quando já seja tarde demais. Numa época em que até o futuro próximo se tornou imprevisível, o Direito não consegue fornecer soluções a priori para problemas e angústias que se multiplicam. Quando isso ocorre, é preciso definir objetivos claros para o futuro da humanidade e fundá-los nos valores essenciais e perenes que vêm desde a antiguidade.

Palavras-Chave: Revolução tecnológica; crise da democracia; mudança climática; limites do Direito.

\footnotetext{
${ }^{1}$ Este artigo foi escrito, em sua maior parte, na Harvard Kennedy School. Sou grato a Sushma Raman e a Mathias Risse pela gentil acolhida no Carr Center for Human Rights. Agradeço, também, a Roberta Thomazoni Mayerle por sua valiosa ajuda na pesquisa das questões ambientais.

${ }^{2}$ Ministro do Supremo Tribunal Federal (Brasil). Professor Titular da Universidade do Estado do Rio de Janeiro - UERJ. Mestre pela Universidade de Yale. Doutor e Livre-Docente pela UERJ. Senior Fellow na Harvard Kennedy School. Lattes: http://lattes.cnpq.br/2430424576721113. Contato: mlrbgab@stf.jus.br.
} 
ABSTRACT: Law is a universal institution that has pretensions of being ubiquitous and complete. However, in a complex, plural and volatile world, its limits and possibilities are shaken by the speed, depth and extent of ongoing transformations, its resulting ethical dilemmas, and the difficulties of forming consensus in the political universe. This article provides a reflection on how the law has attempted to deal with some of the main afflictions of our time, facing demands that include the needs to (i) keep the technological revolution on an ethical and humanistic track, (ii) avoid that democracy be perverted by populist and authoritarian adventures and (iii) prevent solutions to climate change from coming only when it is too late. At a time when even the near future has become unpredictable, law cannot provide a priori solutions to multiplying problems and anxieties. When this happens, we must set clear goals for the future of humanity, basing them on the essential and perennial values that have followed us since antiquity.

KEYWORDS: Technological revolution; democratic recession; climate change; the limits of Law. 


\title{
SUMÁRIO
}

I. INTRODUÇÃO

\author{
PARTE I \\ ALGUMAS LIÇÕES DO SÉCULO XX
}

II. DISTOPIAS, DESEJOS E REALIDADE

III. O MUNDO MELHOROU MUITO: O AVANÇO DOS VALORES ILUMINISTAS

IV. A IMPORTÂNCIA DECISIVA DAS INSTITUIÇÕES

PARTE II

TRANSFORMAÇÕES E AFLIÇÕES DO SÉCULO XXI

V. A REVOLUÇÃO TECNOLÓGICA

VI. A CRISE DA DEMOCRACIA

VII. O AQUECIMENTO GLOBAL

\section{Parte III}

OS DESAFIOS DO NOSSO TEMPO: LIMITES E POSSIBILIDADES DO DIREITO

VIII. ALGUNS RISCOS DA REVOLUÇÃO TECNOLÓGICA

IX. A DEMOCRACIA E SEUS INIMIGOS INTERNOS

X. OS ESFORÇOS CONTRA O AQUECIMENTO GLOBAL

XI. CONCLUSÃO 


\section{INTRODUÇÃO}

$\mathrm{O}$ artigo que se segue procura analisar as relações entre o Direito e três fenômenos que moldam de forma emblemática o mundo contemporâneo. $\mathrm{O}$ primeiro desses fenômenos é a revolução tecnológica ou digital e o limiar da Quarta Revolução Industrial. A conjugação da tecnologia da informação, da inteligência artificial e da biotecnologia produzirá impacto cada vez maior sobre os comportamentos individuais, os relacionamentos humanos e o mercado de trabalho, desafiando soluções jurídicas em múltiplas dimensões. Em segundo lugar, a crise da democracia ronda países de diferentes continentes. Mesmo nas democracias mais maduras, um número expressivo de cidadãos tem abandonado visões políticas moderadas para apoiar minorias radicais, com aumento preocupante da tolerância para com soluções autoritárias. O constitucionalismo democrático precisa reagir aos riscos e às ameaças desses novos tempos. Por fim, afetando de maneira transversal todas as nações do globo, está a questão ambiental. Apesar da persistência de algumas posições contrárias, a maioria esmagadora dos cientistas adverte dos perigos de se retardarem as providências prementes exigidas para conter a mudança climática ${ }^{3}$, que a longo prazo ameaça a própria sobrevivência da vida na Terra.

O Direito, por sua vez, como a grande instituição universal ${ }^{4}$, procura incidir sobre as novas realidades, com sua eterna pretensão de ubiquidade, universalidade e completude. Porém, num mundo COMPLEXO, PLURAL E VOLÁTIL, repleto de dilemas éticos e impasses políticos, seus limites e possibilidades são testados e abalados. A confluência desses fatores produz a conjuntura crítica da atualidade. É nesse ambiente que se procura: manter o avanço tecnológico numa trilha ética e humanista; revitalizar a democracia, incorporando as potencialidades do mundo digital e redesenhando instituições que envelheceram; bem como despertar corações e mentes dos cidadãos e atitudes das autoridades para lidar com a gravidade do aquecimento global e as suas consequências. A história registra que é em momentos críticos que se abrem janelas de oportunidade para mudanças estruturais na política, na economia e nas práticas sociais em geral. Por exemplo: o

\footnotetext{
3 Mudança climática e aquecimento global são expressões frequentemente utilizadas como identificando o mesmo fenômeno. Porém, mais recentemente, tem se preferido a denominação mudança climática, por seu caráter mais abrangente. Ver Room (2019): “Mudanças climáticas ou mudanças climáticas globais são geralmente consideradas um termo mais cientificamente preciso do que o aquecimento global, como a NASA explicou em 2008, em parte porque as mudanças nos padrões de precipitação e no nível do mar provavelmente terão um impacto humano muito maior do que temperaturas sozinho".

${ }^{4}$ Barrozo (2019, p. 09). Mimeografado: “O Direito é a grande instituição universal. Isso significa que, em princípio, ninguém está fora do seu alcance; e tal característica nenhuma outra instituição pode igualar. Na medida em que os sistemas jurídicos domésticos se conectam entre si e com o sistema de direito internacional em uma grande variedade de maneiras, a ubiquidade do Direito aponta para sua universalidade".
} 
período que sucedeu à Segunda Grande Guerra proporcionou ao mundo avanços civilizatórios significativos. É preciso, portanto, nessa quadra em que vivemos, oferecer resistência aos retrocessos, mas liberar a energia criativa do movimento da história, sem temer as inovações e as transformações irreversíveis.

\section{PARTE I}

\section{ALGUMAS LIÇÕES DO SÉCULO XX}

\section{DISTOPIAS, DESEJOS E REALIDADE}

Duas distopias $^{5}$ totalitárias marcaram época no século XX. A primeira delas foi Admirável Mundo Novo, livro de Aldous Huxley publicado em 1932, entre a Primeira e a Segunda Guerra Mundiais, um período caracterizado pelo otimismo tecnológico. A segunda foi 1984, de autoria de George Orwell, publicada em 1949, após a Segunda Guerra, um momento em que se vivia o crescente poderio da União Soviética e o apelo político do comunismo. Um terceiro texto assinalou os anos finais do século passado: O Fim da História, de Francis Fukuyama, publicado em $1989^{6}$ e, depois, expandido em um livro lançado em 19927. O texto foi contemporâneo do fim da Guerra Fria e refletiu a empolgação daquele momento.

Em Admirável Mundo $N_{o v o}{ }^{8}$, Huxley retrata uma organização política futurística, denominada Estado Mundial, na qual inexistem guerras, revoluções ou conflitos sociais. A sociedade é dividida em cinco classes, cada uma delas destinada a cumprir uma função: desde os Alfas, criados para serem líderes, até os Epsilons, que desempenharão os trabalhos manuais. Os embriões eram concebidos em laboratório, numa linha de produção na qual, por manipulação genética e tecnologias de condicionamento, eram desenvolvidos para realizar, com satisfação, o papel social que lhes seria atribuído. Nesse universo, inexistiam figuras como pai, mãe ou gestação. A ordem política e social era organizada para o fim utilitário de maximizar a felicidade de todos e de cada um. Para tanto, foram suprimidos, desde a origem, emoções fortes, desejos afetivos e relações pessoais mais intensas. $\mathrm{Na}$ eventualidade de alguma frustração ou tristeza, consumia-se uma droga capaz de eliminar sentimentos negativos, denominada Soma. Todo o sistema era baseado no prazer, sendo o sexo livre e não monogâmico. Os não conformistas eram exilados. A sociedade, como a conhecemos hoje, subsistia apenas em uma Reserva Selvagem, que as pessoas podiam visitar para ver os horrores de outra época - a nossa! - com violência, rituais religiosos estranhos e sofrimentos. $\mathrm{O}$ único personagem que se rebela contra o modelo do Estado Mundial acaba sucumbindo ao sistema e se

\footnotetext{
${ }^{5}$ Utopia designa um sistema social idealizado e próximo da perfeição. Distopia identifica o oposto: um sistema social opressivo, com variados tipos de coerção.

${ }^{6}$ Fukuyama (1989, p. 03-18).

${ }^{7}$ Fukuyama (1992).

${ }^{8}$ Huxley (1932).
} 
suicida. O aparente paraíso hedonista de Huxley é, na verdade, totalitário e desumanizador.

No livro $1984^{9}$, Orwell narra o contexto assustador e deprimente de um Estado totalitário, fundado no controle social opressivo dos cidadãos, com censura, vigilância, propaganda e brutal repressão. A história se passa em Oceania, um dos três super-Estados em que se dividiu o mundo na sequência de guerras e revoluções internas que se seguiram à Segunda Grande Guerra. Os outros dois Estados "intercontinentais" são Eurásia e Lestásia. Todos vivem em guerra permanente. $\mathrm{O}$ governo é conduzido por um partido único, no qual se cultua a personalidade de um líder cuja existência real é incerta, conhecido como Big Brother. A sociedade é dividida em três classes: a alta, que abriga a reduzida elite partidária, a média e o proletariado. Os Ministérios são designados por nomes que representam o seu oposto: o da Paz cuida da guerra, o da Abundância administra o racionamento, o do Amor promove tortura e lavagem cerebral e o da Verdade trata da propaganda e da revisão da história. O personagem principal, Winston Smith, trabalha no Ministério da Verdade, reescrevendo a história de acordo com as demandas do partido. Winston é inconformado com o sistema opressivo, em que além de não haver liberdade de pensamento, até mesmo seu relacionamento amoroso tem que ser clandestino. Ele procura se juntar ao movimento de resistência, mas é vítima de uma armadilha, sendo preso, longamente torturado e submetido a lavagem cerebral. No final melancólico do livro, Winston passa a apoiar o partido e a amar Big Brother.

Diferentemente dos dois primeiros, o texto de Fukuyama não é ficção futurista, mas, ao contrário, teve a pretensão de retratar a realidade histórica, corrente e futura. Dois meses após o discurso de Mikhail Gorbachev, nas Nações Unidas, anunciando que a União Soviética não mais interferiria nos assuntos dos seus então satélites do leste europeu, o autor proferiu, em fevereiro de 1989, a palestra que lançaria as bases do seu artigo $O$ Fim da História, publicado meses depois, e do livro que aprofundaria o tema ${ }^{10}$. Seu argumento era simples: com o fim da guerra fria e a iminente derrocada do comunismo, o embate ideológico que marcara o século $\mathrm{XX}$, entre capitalismo e comunismo, assim como a guerra fria que lhe servia de pano de fundo, haviam chegado ao fim. A democracia liberal, fundada no Estado de direito, no livre mercado, nas liberdades individuais e no direito de participação política, consagrou-se como o ponto culminante da evolução ideológica da humanidade ${ }^{11}$. Segundo ele, Marx estava errado: o capitalismo, e não o comunismo, prevaleceu no final. Hegel, por sua vez, estava certo quando previu que uma forma

\footnotetext{
${ }^{9}$ Orwell (2007).

${ }^{10}$ Fukuyama (1989, p. 03-18; 1992).

${ }^{11}$ Fukuyama (1989, p. 4): “What we may be witnessing is not just the end of the Cold War (...), but the end of history as such: that is, the end point of mankind's ideological evolution and the universalization of Western liberal democracy as the final form of human government".
} 
perfeitamente racional de sociedade e de Estado um dia se tornaria vitoriosa ${ }^{12}$. Poucos meses após a publicação do artigo, a queda do muro de Berlim, em 9 de novembro de 1989 e, mais à frente, a dissolução da União Soviética, em 26 de dezembro de 1991, pareciam dar razão a Fukuyama. O tempo demonstraria, todavia, que o vaticínio do fim da história era mais um desejo - wishful thinking do que uma realidade.

Nenhuma das duas distopias se tornou realidade, seja no próprio século XX, seja nesse quarto inicial do século XXI. É certo que 1984 tinha seu enredo baseado em riscos históricos mais próximos, à vista das experiências do nazismo e do stalinismo. Já o Admirável Mundo Novo, como obra de ficção científica, mirava um futuro mais remoto. Nada obstante, ambas trazem alertas importantes, que vêm do século $\mathrm{XX}$, para os riscos reais da combinação entre política, autoritarismo, tecnologia e engenharia genética. Profecias assustadoras, como as dessas duas obras, nem sempre são formuladas como antecipação do que vai efetivamente acontecer, mas, justamente ao contrário, servem para despertar as consciências para perigos que podem germinar na sociedade. Quanto à democracia constitucional, é correta a constatação de que ela foi a ideologia vitoriosa do século $X X^{13}$. Sem embargo, nesse início do novo século, ela enfrenta contestações e desafios relevantes. Em suma: as distopias não se realizaram, mas a história não acabou.

\section{O MUNDO MELHOROU MUITO: O AVANÇO DOS VALORES ILUMINISTAS}

O século $X X$ talvez não tenha sido tão breve, mas certamente foi uma era de extremos $^{14}$ : teve, simultaneamente, a marca de guerras e genocídios, de um lado, e a consagração dos direitos humanos e a expansão da democracia, de outro. Guerras foram muitas: mundiais, como a Primeira, de 1914 a 1917, e a Segunda, de 1939 a 1945; e localizadas, como as da Coréia, do Vietnam e do Golfo, entre outras. Além de uma prolongada guerra fria, com o risco de conflito nuclear. Foram dois os holocaustos: o de mais de 1,5 milhão de armênios pelo Império Otomano, entre 1915 e 1923, e o de mais de 6 milhões de judeus pelos nazistas, entre 1941 e 1945. Alguns incluiriam nessa lista, também, o massacre de mais de 500 mil Tutsi, em Ruanda, em 1994. O século foi igualmente palco da Revolução Russa, de 1917, e da grande depressão do mundo capitalista, a partir de 1929. Também foi o cenário da ascensão e da queda do fascismo, do nazismo e do comunismo, bem como da eclosão do fundamentalismo islâmico.

\footnotetext{
${ }^{12}$ Fukuyama (1989, p. 04).

${ }^{13}$ Em 1900, nenhum país do mundo tinha seus governantes eleitos por sufrágio universal. Em dezembro de 1999, 119 países poderiam ser identificados como democráticos. Ver Freedom House (1999). Ver também, Barroso (2019).

${ }^{14}$ A era dos extremos: o breve século XX é o título do livro célebre de um dos mais proeminentes historiadores do século XX, Eric Hobsbawm, publicado em 1994.
} 
Após a Segunda Guerra Mundial, houve a criação das Nações Unidas e a aprovação de diversas declarações de direitos humanos. Da metade para o quarto final do século, ocorreram inovações importantes nos costumes e na cultura, que incluíram o desenvolvimento da pílula anticoncepcional, a emancipação feminina, a conquista de direitos civis pelos negros e o início do reconhecimento de igualdade para os grupos LGBT. Mesmo após a dissolução da União Soviética, o século ainda continuou acelerado, com o desenvolvimento e difusão dos computadores pessoais, dos telefones celulares e, sobretudo, a revolução trazida pela internet, conectando quase todo o mundo em tempo real. Foi, igualmente, a era do rádio, da televisão, do jazz, do rock n' roll, dos Beatles e da bossa nova. De Pablo Picasso, Frida Khalo e Andy Warhol. E, também, de Villa-Lobos e Caetano Velloso. A pluralidade, intensidade e velocidade dos eventos, interpretados sob pontos de vista ideológicos e existenciais diversos, levaram a avaliações contrapostas acerca do impacto que o período produziu na história da humanidade em geral e no século XXI, que se iniciou em seguida.

Uma visão geral negativa e até pessimista do século $X X$ é exposta pelo historiador inglês Eric Hobsbawm, em aclamado livro publicado em 1994. A obra se inicia com declarações de 12 intelectuais relevantes, começando por Isaiah Berlin, que se referem ao "breve século XX" - período que vai do início da Primeira Guerra à dissolução da União Soviética - como "o mais terrível", "o mais violento", "século de massacres e guerras". O próprio Hobsbawm afirmou que o século começou com catástrofe e terminou em crise, com uma curta "época de ouro" de crescimento econômico e transformação social, que vai do final da Segunda Guerra ao início dos anos $70^{\prime \prime 15}$. Na visão do autor, tanto o comunismo quanto o capitalismo fracassaram, e o futuro não é promissor. Para ele, o mundo do terceiro milênio certamente continuará a ser marcado pela violência política ${ }^{16}$. O livro foi concluído imediatamente após o fim da guerra fria e do desmoronamento do projeto socialista. Tendo sido um ativo intelectual marxista, Hobsbawm não viu ali o triunfo da democracia liberal e do livre mercado, mas a prevalência de um sistema que considerava incapaz de trazer justiça social e estabilidade. Para ele, "o velho século terminou mal"17.

Não se devem minimizar as vicissitudes do século XX, relatadas com maestria por Eric Hobsbawm, nem os riscos de um capitalismo sem competidores ideológicos. Porém, não é possível, tampouco, fechar os olhos para um fato inegável: a humanidade iniciou o século XXI em condições melhores do que jamais esteve. Olhando em perspectiva histórica, o mundo que se desenvolveu sob o signo das ideias do Iluminismo, consagradas ao final do século XVIII - razão, ciência, humanismo e progresso ${ }^{18}$-, é de evolução contínua em múltiplos domínios:

\footnotetext{
${ }^{15}$ Hobsbawm (1994, p. 06).

${ }^{16}$ Hobsbawm (1994, p. 460).

${ }^{17}$ Hobsbawm (1994, p. 17).

18 Pinker (2018).
} 
vivemos mais e melhor, num planeta com menos guerras, menos desnutrição, menos pobreza, maior acesso ao conhecimento, mais direitos, inclusive para minorias secularmente discriminadas, como mulheres, negros e gays. Mesmo a ética animal entrou no radar da sociedade. $O$ século $X X$, com seus avanços na ciência, na medicina, na tecnologia digital, na democracia não simboliza, por isso mesmo, um período de decadência da condição humana ${ }^{19}$. Justamente ao revés, foi o século que desfez ilusões e nos tornou mais exigentes, mais realistas e livres de narrativas abrangentes imaginárias. Parte do romantismo foi trocada pela exigência de comprovação empírica do que funciona e do que não funciona.

Em um livro repleto de dados reconfortantes, Steven Pinker documenta essa evolução, com fartura de dados e de informações. A expectativa de vida, em meados do século XVIII, na Europa e nas Américas, era em torno de 35 anos. No início do século XXI, era superior a $70^{20}$. A desnutrição ainda afeta, tragicamente, $13 \%$ da população mundial. Mas, em 1947, esse percentual era de $50 \%{ }^{21}$. A pobreza extrema caiu de $90 \%$ para $10 \%$ em 200 anos, tendo o salto na curva ocorrido no quarto final do século XX. Ademais, a tecnologia e a globalização modificaram o significado do que é ser pobre ${ }^{22}$. Apesar das muitas nuances envolvendo a desigualdade persistente, o fato objetivo é que o coeficiente Gini - índice internacional utilizado para medir a desigualdade social - revela que ela está em declínio ${ }^{23}$. A educação ainda enfrenta graves deficiências em toda parte, e há metas específicas em relação ao tema fixadas em documentos internacionais ${ }^{24}$. Porém, o avanço é crescente. A alfabetização, que era privilégio de poucos, mesmo quando já avançado o século XIX, hoje alcança $87 \%$ da população mundial ${ }^{25}$. Quanto à paz, a guerra permanente deixou de ser $\mathrm{o}$ estado natural das relações entre os países. E, embora, tristemente, ainda existam guerras geograficamente limitadas, a quase totalidade das nações do mundo tem o compromisso de não entrar em conflito bélico, salvo em legítima defesa ou com a aprovação da $\mathrm{ONU}^{26}$.

Esses avanços civilizatórios são confirmados pelo IDH - Índice de Desenvolvimento Humano, adotado pelo Programa de Desenvolvimento das Nações Unidas, que mede a qualidade de vida das pessoas com base na expectativa de vida, educação e renda per capita ${ }^{27}$. Os progressos referidos acima sugerem uma

\footnotetext{
${ }^{19}$ Nas palavras de Harari (2017, p. 21): “Tendo garantido níveis sem precedentes de prosperidade, saúde e harmonia, e dado nosso histórico passado e nossos valores atuais, os próximos alvos da humanidade provavelmente serão a imortalidade, a felicidade e a divindade" (tradução livre).

${ }^{20}$ Pinker (2018, p. 53-55).

${ }^{21}$ Pinker (2018, p. 71).

22 Pinker (2018, p. 87; 117).

23 Pinker (2018, p. 105).

${ }^{24}$ Na Agenda de Desenvolvimento Sustentável para 2030, das Nações Unidas, aprovada em 2015, o Objetivo 4 é o seguinte: "Assegurar a educação inclusiva e equitativa e de qualidade, e promover oportunidades de aprendizagem ao longo da vida para todos".

${ }^{25}$ Pinker (2018, p. 236).

${ }^{26}$ Pinker (2018, p. 13; 163).

${ }^{27}$ United Nations (2019?).
} 
marcha na direção certa, embora não na velocidade desejada. A superação da pobreza extrema e a redução das desigualdades continuam a ser causas inacabadas da humanidade. Ainda assim, é bom desfazer a crença de que o mundo está em declínio, prestes a cair no domínio caótico de miséria, guerras, revoluções, terrorismo, tráfico de drogas, intolerâncias diversas e epidemias. Há momentos em que a fotografia parece assustadora, mas é sempre necessário olhar o filme inteiro.

\section{A IMPORTÂNCIA DECISIVA DAS INSTITUIÇÕES}

Uma das lições do século XX é o papel decisivo das instituições no desempenho político e econômico dos países. Instituições são as "regras do jogo" e os mecanismos necessários ao seu cumprimento. Tais regras, formais e informais, instituem limites e incentivos na interação humana ${ }^{28}$. São padrões de comportamento e de relacionamento à vista da Constituição, leis, regulamentos e normas éticas, bem como de costumes e práticas sociais nas áreas mais diversas. Também permeiam o conceito atitudes sociais relativamente a valores como trabalho, justiça, confiança, integridade e cooperação, entre outros. Uma constatação essencial é a de que, quando as instituições formais não funcionam adequadamente, institucionalizam-se práticas informais, muitas vezes contra legem $^{29}$. O que explica as diferenças no nível de realizações das diferentes sociedades? O papel das instituições políticas e econômicas na construção das nações, determinando seu sucesso ou fracasso, é objeto de vasta literatura acadêmica. Um dos autores mais relevantes sobre o tema foi Douglass C. North, covencedor do Prêmio Nobel de Economia do ano de 1993, cujas ideias permeiam as reflexões que se seguem.

No plano político, instituições existem para criar uma ordem estável, que diminua o nível de incerteza nas interações humanas ${ }^{30}$. No plano econômico, as instituições são responsáveis, em última análise, pelas oportunidades existentes numa dada sociedade, já que são fatores decisivos para o comportamento humano e para a formação dos custos de produção e de transação ${ }^{31}$. Elas definem e limitam

\footnotetext{
${ }^{28}$ North (2018, p. 13).

${ }^{29}$ Por exemplo: onde o sistema de justiça funciona mal, aumenta a violência privada; onde a burocracia impõe ônus excessivos, desenvolvem-se esquemas alternativos de propinas; onde a tributação é desproporcional, multiplicam-se os artifícios para a sonegação. Assim é, porque sempre foi.

${ }^{30}$ North $(2018$, p. 13; 16-17; 197). North faz uma importante distinção conceitual entre instituições e organizações. Instituições, como visto, são as regras do jogo. As organizações (partidos políticos, empresas, sindicatos, universidades etc.) são os jogadores. As regras do jogo não se confundem com as estratégias dos jogadores.

${ }^{31}$ Custo de transação é o custo de fazer negócios, comprando e vendendo bens ou serviços. Eles incluem despesas com comunicação, serviços jurídicos, obtenção de informações adequadas, controle de qualidade e mesmo transporte. V. Business Dictionary (2019?). Se num dado mercado é difícil obter uma linha telefônica, comprar uma peça de reposição ou ver um processo judicial
} 
as escolhas que as pessoas podem fazer. Os incentivos decorrentes do arranjo institucional vigente são determinantes na definição de quais habilidades e conhecimentos serão mais valiosos e quais comportamentos recompensam melhor os indivíduos e as empresas ${ }^{32}$. A seguir, alguns exemplos de como a maior ou menor eficiência das instituições traça o destino das nações.

O papel das instituições políticas e econômicas foi o marco divisor da trajetória de países como Espanha e Inglaterra. No início do século XVII, a Espanha era a grande potência mundial e a Inglaterra uma ilha relativamente secundária no contexto da Europa. Todavia, ao longo do século, as instituições inglesas evoluíram na direção da afirmação do Parlamento, com maior garantia dos direitos de propriedade, um sistema de justiça imparcial, ampliação da liberdade política e, sobretudo, da liberdade econômica. A Espanha, por sua vez, enfrentou a crise fiscal trazida por guerras sucessivas exacerbando o poder monárquico, aumentando tributos, realizando confiscos de propriedades e desenvolvendo uma burocracia centralizadora e monopolista, voltada para os interesses da Coroa. Quando o século XVII chegou ao fim, a Espanha vivia um processo de estagnação que duraria até o quarto final do século XX, enquanto a Inglaterra preparara o caminho para a Revolução Industrial e para tornar-se a maior potência mundial.

Outro contraste relevante que comprova o papel das instituições é o que opõe os Estados Unidos e a América Latina. Nos Estados Unidos, não tendo sido possível a exploração do trabalho indígena, restou aos colonos a necessidade do trabalho próprio. Além disso, a ideia inglesa de limitação do poder e de algum grau de participação política da cidadania, o pluralismo religioso e a garantia dos direitos de propriedade definiram uma trajetória que desaguaria em uma Constituição escrita, separação de Poderes, declaração de direitos, autonomia dos Estados e pujança econômica. O quadro institucional ofereceu os incentivos adequados para estímulo da atividade econômica produtiva e nem mesmo uma das piores guerras civis da história alterou essa realidade. Já na maior parte da América Latina, impôsse o trabalho forçado às populações nativas, bem como sua conversão ao cristianismo. Além disso, o continente foi herdeiro de um modelo autoritário, centralizador, em que a Igreja não era separada do Estado e no qual a Coroa controlava todas as atividades econômicas, delegadas a particulares por diferentes métodos de favoritismo ${ }^{33}$.

julgado em tempo razoável, o custo de transação aumenta significativamente. O trabalho considerado seminal nessa matéria é de Coase (1937, p. 386-405).

${ }^{32}$ North $(2018$, p. 135).

33 Sobre o tema, v. North (2018, p. 173-176). Após a independência, os países latino-americanos importaram, de uma maneira geral, o modelo constitucional norte-americano. Tal fato, todavia, não foi capaz de assegurar a efetividade das novas normas, nem tampouco de transmudar as disfunções arraigadas nas instituições espanholas e lusitanas, que se perpetuaram no tempo e ainda hoje cobram seu preço. 
O papel fundamental das instituições foi retomado no livro merecidamente aclamado de Daron Acemoglu e James A. Robinson, Why nations fail ${ }^{34}$, cujas ideias são o fio condutor dos parágrafos a seguir. A tese central da obra é a de que as origens do poder, da prosperidade e da pobreza das nações não se encontram - ao menos na sua parcela mais relevante - na geografia, na cultura ou na ignorância acerca de qual seja a coisa certa a se fazer. A real razão do sucesso ou do fracasso dos países está na existência ou não de instituições políticas e econômicas inclusivas. As instituições políticas estabelecem a distribuição de poder na sociedade e os fins para os quais esse poder será empregado. Por essa razão, embora sejam as instituições econômicas as determinantes da riqueza ou da penúria dos países, elas são produto das decisões políticas tomadas pelas elites governantes. Como consequência, existe intensa sinergia entre ambas: como regra geral, instituições políticas inclusivas geram instituições econômicas inclusivas e, inversamente, instituições políticas extrativistas geram instituições econômicas extrativistas ${ }^{35}$.

A demonstração de que a geografia e a cultura não desempenham o papel que tradicionalmente se supôs no destino das nações é feita com casos reais e emblemáticos. Como o de Nogales, cidade que é cortada ao meio por uma cerca, ficando metade no Arizona, nos Estados Unidos, e a outra metade em Sonora, no México. Em Nogales, Arizona, a renda média anual por domicílio é de $30 \mathrm{mil}$ dólares e a cidade tem bons serviços de eletricidade, telefonia, saúde e transportes, além de lei e ordem. Em Nogales, Sonora, a situação é bem pior: a renda média anual por domicílio é um terço da que foi apurada do outro lado da fronteira, os serviços públicos são bastante deficientes, a criminalidade é alta e abrir um negócio é bastante arriscado. A fotografia de cada um dos lados da cerca exibe mundos distintos. Paralelo semelhante, mas ainda mais dramático, pode ser traçado na comparação entre Coréia do Sul e Coréia do Norte. O padrão de vida no Sul é similar ao de Portugal e Espanha. No Norte, é próximo do da África subsaariana, sendo um décimo do padrão da Coréia do Sul. A fotografia noturna, tirada por satélite, documenta de forma desconcertante a realidade desigual: enquanto a Coréia do Sul aparece iluminada em toda a sua extensão, a Coréia do Norte é uma mancha escura, com alguns poucos pontos de luz na capital. Na mesma linha comparativa, os indicadores da Alemanha Ocidental e da Oriental eram significativamente discrepantes. Em todos esses casos, geografia e cultura eram as mesmas $^{36}$.

Mas o que vêm a ser, exatamente, instituições políticas e econômicas inclusivas? Vejamos as instituições políticas, em primeiro lugar. As Revoluções Inglesa, Americana e Francesa afastaram do poder as elites que historicamente o ocupavam (absolutistas, colonialistas, nobreza e clero) e cuidaram, progressivamente, de

\footnotetext{
${ }^{34}$ Acemoglu e Robinson (2013).

${ }^{35}$ Acemoglu e Robinson (2013, p. 43; 80-81).

${ }^{36}$ Acemoglu e Robinson (2013, p. 7-9; 71-73).
} 
conferir direitos políticos aos cidadãos. O poder político foi sendo limitado, os direitos fundamentais foram sendo ampliados e os governos se tornaram mais responsivos à vontade popular. Terras foram distribuídas de forma relativamente justa $^{37}$ e os direitos de propriedade, inclusive intelectual, passaram a ser valorizados e respeitados. Um Judiciário independente e eficiente arbitrava os conflitos entre particulares ou destes com o Estado. Deve-se anotar que a democracia liberal não é, por si, garantia de que as instituições políticas serão inclusivas. É certo, porém, que eleições regulares, com competição política livre e plural, têm a tendência natural de produzir esse resultado ${ }^{38}$.

As instituições econômicas, por sua vez, começaram a se tornar inclusivas ao longo do processo histórico que conduziu à Revolução Inglesa, apelidada de Revolução Gloriosa (1689). Ali se deu a limitação definitiva dos poderes do rei e a afirmação do Parlamento, que passou, inclusive, a deter competências relativamente às instituições econômicas. Deu-se sequência, então, à política de abolição dos monopólios domésticos e internacionais, com expressiva abertura da economia a diferentes segmentos da sociedade, o que serviu como incentivo para investimentos, comércio e inovação. Também se pôs fim à tributação arbitrária e confiscatória. Tais transformações fomentaram o empreendedorismo e pavimentaram o caminho para a Revolução Industrial, que foi o marco inicial das experiências de desenvolvimento sustentável no mundo. A primeira beneficiária foi, naturalmente, a Grã-Bretanha, seguida de outros países da Europa Ocidental que embarcaram no trem histórico da liberdade econômica e da inovação tecnológica. Ficaram para trás os modelos absolutistas extrativistas, como o Império Austro-Húngaro, o Império Otomano, a Rússia e a China, para citar alguns $^{39}$.

O ambiente natural das instituições econômicas inclusivas é o da economia de mercado, em que indivíduos e empresas podem produzir, comprar e vender quaisquer produtos e serviços que desejem. No reverso da medalha estão as instituições políticas extrativistas, geradoras de instituições econômicas igualmente extrativistas, que transferem riqueza e poder para as elites. As nações fracassam, nos dias de hoje, quando não conseguem dar a todos segurança jurídica, confiança e igualdade de oportunidades para pouparem, investirem, empreenderem e inovarem. Países que se atrasaram na história foram conduzidos por elites

\footnotetext{
${ }^{37}$ Acemoglu e Robinson (2013, p. 37), expõem, contrastando os Estados Unidos com a América Latina, o modo de distribuição de terras em um e outra: “Nos Estados Unidos, uma longa série de atos legislativos, desde a Lei de Terras (Land Ordinance) de 1785 até a lei conhecida como Homestead Act, de 1862, deu amplo acesso às terras de fronteira. Embora os povos indígenas tivessem sido marginalizados, isso criou uma fronteira igualitária e economicamente dinâmica. Na maioria dos países latino-americanos, entretanto, as instituições políticas criaram um resultado muito diferente. Terras de fronteira foram alocadas para os politicamente poderosos e aqueles com riqueza e contatos, tornando essas pessoas ainda mais poderosas" (tradução livre).

${ }^{38}$ Acemoglu e Robinson (2013, p. 102-103; 105; 197; 243).

${ }^{39}$ Acemoglu e Robinson (2013, p. 50; 62; 68; 396).
} 
extrativistas e autorreferentes, que controlam um Estado apropriado privadamente e distribuem por poucos os frutos do progresso econômico limitado que ele é capaz de produzir. Os mecanismos para tanto incluem monopólios, concessões, licenças, liberação de empréstimos públicos, empresas estatais e uma profusão de cargos públicos de livre nomeação. Ao longo da história, instituições extrativistas têm prevalecido na América Latina, na África, na Ásia e em países do leste europeu ${ }^{40}$.

Seria, então, a pobreza e o atraso uma irreversibilidade, um determinismo histórico? A resposta é negativa. Pode não ser fácil, mas é sempre possível transformar instituições extrativistas em inclusivas, tomando a rota da prosperidade. A história é um caminho que se escolhe e não um destino que se cumpre. Instituições inclusivas, como visto, favorecem o crescimento econômico e o avanço tecnológico. As inovações que se produzem nesse ambiente são acompanhadas pelo que o célebre economista austríaco Joseph Schumpeter denominou de "destruição criativa", que é a substituição do velho pelo novo ${ }^{41}$. Novas tecnologias e novas empresas passam a atrair os investimentos, promovendo a redistribuição de poder e riqueza. Esse processo, como intuitivo, produz vencedores e perdedores ${ }^{42}$. Porque assim é, onde prevalecem instituições extrativistas, as elites dominantes não apenas não incentivam a destruição criativa como, mais que isso, empenham-se para impedir as transformações. O fato, porém, é que não há crescimento sem destruição criativa e verdadeira inovação ${ }^{43}$.

Por essa razão, mudanças institucionais relevantes são, em regra, produzidas por conjunturas críticas que as coloquem em xeque, abalando o equilíbrio político e econômico existente ${ }^{44}$. Quando essas viradas históricas ocorrem, abre-se uma janela de oportunidade para a substituição ou transformação das instituições políticas e econômicas. Eventos como a Peste Negra, a Revolução Industrial, a Grande Depressão, o término da $2^{a}$ Guerra Mundial, o fim do colonialismo africano, a superação das ditaduras militares na América Latina e a queda do Muro de Berlim são alguns exemplos desses momentos catalisadores de transformações. As conjunturas críticas são o cenário provável da mudança institucional, mas,

\footnotetext{
40 Acemoglu e Robinson (2013, p. 372; 401).

${ }^{41}$ Schumpeter (2008, p. 83): “O impulso fundamental que define e mantém o motor capitalista em movimento vem dos novos bens de consumo, dos novos métodos de produção ou transporte, dos novos mercados, das novas formas de organização industrial que a empresa capitalista cria".

42 O tear a vapor, marco da Revolução Industrial, retirou a indústria tradicional de algodão do mercado; na indústria da música, o $\mathrm{CD}$ abalou o vinil e foi praticamente erradicado pelos downloads e streamings digitais; os meios de comunicação impressos, como jornais e revistas, vivem a crise trazida pelo predomínio da informação online em tempo real; as empresas de telefonia sofrem a concorrência de meios alternativos de comunicação, como Whatsapp, Skype e outros.

43 Acemoglu e Robinson (2013, p. 84; 207; 442).

44 Acemoglu e Robinson (2013, p. 432-433): “Conjunturas críticas são eventos importantes que rompem o equilíbrio político e econômico existente em uma ou várias sociedades. (...) As conjunturas críticas são pontos de inflexão históricos" (tradução livre).
} 
naturalmente, não há garantia de que ela vá ocorrer ${ }^{45}$. Note-se, também, que mesmo quando um evento drástico quebra os pilares da velha ordem, o processo de mudança e sua consolidação se dão de maneira incremental, e não como um fato datado $^{46}$.

\section{PARTE II}

\section{TRANSFORMAÇÕES E AFLIÇÕES DO SÉCULO XXI}

\section{A REVOLUÇÃo TECNOLÓGICA ${ }^{47}$}

Tudo começou há cerca de 13,5 bilhões de anos, quando ocorreu o Big Bang e surgiu o universo, com seus elementos fundamentais: matéria, energia, tempo e espaço. Pouco mais de 9 bilhões de anos depois, formou-se o sistema solar. E, com ele, a Terra, onde os primeiros sinais de vida orgânica remontam a 4 bilhões de anos. Os antepassados mais remotos dos humanos teriam aparecido há 2,5 milhões de anos. Nosso ancestral direto, o homo sapiens, tem sua linhagem reconduzida a mais ou menos $70 \mathrm{mil}$ anos. Somos crianças no universo. A escrita foi inventada entre 3.500 e 3.000 a.C. Até então, obras emblemáticas da história da humanidade, como a Bíblia Hebraica, a Ilíada grega, o Mahabarata indiano e as primeiras escrituras budistas passaram de geração a geração como narrativas orais. Três grandes revoluções moldaram a história da humanidade: a Revolução Cognitiva, a Revolução Agrícola e a Revolução Científica ${ }^{48}$.

A Revolução Cognitiva deu-se por volta de 70 mil anos atrás, marcando verdadeiramente o início da história. A partir desse momento, desenvolve-se o traço distintivo essencial que singulariza a condição humana, que é a comunicação, a linguagem, a capacidade de transmitir informação, conhecimento e ideias. Registros que passam de uma geração para a outra, sem que a transmissão se dê geneticamente, via DNA ${ }^{49}$. A Revolução Agrícola teve lugar há cerca de 10 mil anos, com o domínio de técnicas de plantio e a domesticação de animais. A possibilidade de produzir alimentos em vez de ir buscá-los ou caçá-los fixou os grupos humanos em lugares determinados, fazendo com que passassem de nômades a sedentários. Começam a surgir as cidades, os Estados e os Impérios. Por fim, veio a Revolução Científica, que tem início ao fim do Renascimento, na virada do século XV para o XVI, e se estende até os dias de hoje. Um rico período da história da humanidade, que incluiu a publicação da obra revolucionária de Nicolau Copérnico e a conquista

${ }^{45}$ Acemoglu e Robinson (2013, p. 111; 431).

${ }^{46}$ North $(2018$, p. 18): "Ademais, as instituições comumente mudam antes de forma incremental que de modo descontínuo".

${ }^{47}$ As informações sobre a evolução cósmica e humana veiculadas nesse tópico foram colhidas, em sua maior parte, em: Harari (2015; 2017), Gleizer (2012) e Hawking (2018).

${ }^{48}$ Harari (2015, p. 03; 15; 77; 122; 127; 130; 247); Gleizer (2012, p. 110; 237; 240); Hawking (2018, p. 47; $71 ; 73)$.

${ }^{49}$ Hawking (2018, p. 76). 
da lua, o Iluminismo e a Revolução Industrial, até chegar ao mundo interligado por computadores. Éramos 500 milhões de pessoas em 1500, ao final da Idade Média. Somos 7 bilhões hoje ${ }^{50}$.

O conhecimento convencional se firmou no sentido de que ocorreram, historicamente, três Revoluções Industriais. A primeira teve início na segunda metade do século XVIII e prolongou-se pelo século XIX, sendo seus marcos principais o desenvolvimento de novos equipamentos na indústria têxtil, o avanço nas técnicas de produção do ferro, a construção de estradas de ferro, o emprego da água e, sobretudo, do vapor como fonte de energia para a mecanização da produção em geral. A Segunda Revolução Industrial situou-se entre o final do século XIX e as primeiras décadas do século XX, com a expansão de indústrias como aço, petróleo e tendo como símbolos o telefone, a lâmpada elétrica, o motor de combustão interna, o carro, o avião e, notadamente, o uso da energia elétrica para massificação da produção. A Terceira Revolução Industrial aconteceu da metade para o final do século XX, estendendo-se até os dias de hoje. Caracterizou-se pelo avanço da indústria eletrônica, dos grandes computadores (mainframe computers) e pela substituição da tecnologia analógica pela digital. Também conhecida, por isso mesmo, como Revolução Digital, a nova tecnologia permitiu a massificação do computador pessoal, do telefone celular inteligente e, conectando bilhões de pessoas em todo o mundo, a internet. Quem quiser eleger um protagonista para cada uma das três revoluções poderia arriscar o vapor, a eletricidade e a rede mundial de computadores.

A Revolução digital de fato transformou profundamente a maneira como se realiza uma pesquisa, fazem-se compras de mercadorias, reserva-se um voo ou ouve-se música, para citar alguns exemplos ${ }^{51}$. A sociedade contemporânea vive sob a égide de um novo vocabulário, uma nova semântica e uma nova gramática. A linguagem dos nossos dias inclui um conjunto de termos recém incorporados, sem os quais, no entanto, já não saberíamos mais viver. Para citar alguns: Google, Windows, Mac, Whatsapp, Telegram, Uber, Dropbox, Skype, Facetime, Facebook, Twitter, Instagram, Waze, Spotify, Amazon, Google maps, Google translator, iTunes, Netflix, YouTube. Para os solteiros, tem o Tinder, também. Não há setor da economia tradicional que não tenha sido afetado. Indivíduos e empresas estão em busca de adaptação, inovação e novos modelos de negócio. Como bússola desse caminho, procura-se, também, uma nova ética, que consiga combinar criatividade, ousadia, liberdade e, ao mesmo tempo, privacidade, veracidade, proteção contra hackers e contra a criminalidade online.

\footnotetext{
${ }^{50}$ Harari (2015, p. 247).

${ }^{51}$ No Supremo Tribunal, hoje, a maior parte dos processos é eletrônica. O interessado faz o upload da sua petição onde estiver. O Ministro pode despachar acessando o sistema de onde estiver. E pode assinar eletronicamente a decisão por meio de um app, esteja em Brasília, Londres ou Vassouras.
} 
A velha economia não morreu. Ainda há gente que frequenta supermercados, livrarias e lojas em shopping centers. Mas o fato insuperável é que a economia baseada nas interações pessoais, bem como na produção agrícola e industrial, na transformação de matérias primas e na elaboração de bens materiais - ouro, petróleo, fábricas, trigo - cede espaço à nova economia, cuja principal fonte de riqueza é a propriedade intelectual, o conhecimento e a informação ${ }^{52}$. Há um século, uma commodity era responsável pelo crescimento exponencial de uma indústria: o petróleo. Reguladores antitruste tiveram de intervir para evitar a excessiva concentração de poder econômico. Nos dias de hoje, as preocupações que no início do século eram despertadas pelas empresas petrolíferas transferiram-se para uma nova indústria: a que lida com dados. Há inquietações diversas, que incluem concorrência, tributação, privacidade e desemprego. Amazon, Apple, Facebook, Microsoft e Google estão entre as empresas mais valiosas do mundo. É a chamada economia de dados ${ }^{53}$.

Já agora se fala da Quarta Revolução Industrial, como desdobramento da Revolução Digital. De acordo com Klaus Schwab, fundador do Fórum Econômico Mundial e autor de artigo e livro específicos sobre o tema ${ }^{54}$, a Quarta Revolução Industrial é produto da fusão de tecnologias, que está misturando as linhas entre as esferas física, digital e biológica e, em alguma medida, redefinindo o que significa ser humano. Comparada com as Revoluções anteriores, esta se desenvolve em velocidade exponencial, em vez de linear ${ }^{55}$. Inovações e avanços tecnológicos constroem esse admirável mundo novo ${ }^{56}$ da biotecnologia, da inteligência artificial, da robótica, da impressão em 3-D, da nanotecnologia, da computação quântica, de carros autônomos e da internet das coisas. Algoritmo vai se tornando o conceito mais importante do nosso tempo ${ }^{57}$. O futuro é imprevisível.

Em resumo: durante boa parte da história da humanidade, o principal ativo foi a propriedade da terra. Na era moderna, sobretudo após a Revolução Industrial, máquinas, fábricas, fontes de energia e meios de produção em geral se tornaram mais importantes. No século XXI, a tecnologia da informação e o controle sobre os dados transformaram-se nos grandes ativos. A evolução econômica, portanto,

\footnotetext{
${ }^{52}$ Nas palavras de Goodwin (2015), “Uber, a maior empresa de táxis do mundo, não possui veículos. Facebook, o proprietário de mídia mais popular do mundo, não cria conteúdo. Alibaba, o varejista mais valioso, não tem estoque. E o Airbnb, o maior provedor de acomodações do mundo, não possui imóveis. Algo interessante está acontecendo".

${ }^{53}$ The Economist (2017a, p. 09; 2017b, p. 19-22).

${ }^{54}$ Schwab $(2017 ; 2016)$.

${ }^{55}$ Schwab (2016).

${ }^{56}$ Como descrito na Parte I desse artigo, Admirável Mundo Novo é o título do livro clássico de Aldous Huxley que tem como pano de fundo os riscos da evolução da biotecnologia. Para os mais jovens, livro é um meio de transmissão de conhecimento e informação impresso em papel e encadernado, que podia ser adquirido em lojas denominadas livrarias, das quais ainda existem algumas remanescentes.

${ }^{57}$ Harari (2017, p. 83), onde também assinala: “Algoritmo é um conjunto metódico de passos que pode ser usado para fazer cálculos, resolver problemas e tomar decisões" (tradução livre).
} 
atravessou quatro estágios: caça e coleta, agricultura, indústria e informação. Já agora, a fusão entre a tecnologia da informação e a biotecnologia acena com um novo estágio, no qual se antecipa a integração entre o físico e o virtual, o humano e o mecânico. A seleção natural sendo substituída pelo desenho inteligente ${ }^{58}$. Um mundo de promessas, desafios e novos riscos.

\section{A CRISE DA DEMOCRACIA}

$\mathrm{O}$ século $\mathrm{XX}$ foi cenário de ditaduras diversas, de um lado e de outro do espectro político. Algumas foram ferozes e genocidas, fundadas em ideologias abrangentes e de dominação, como a Alemanha de Hitler e a União Soviética de Stalin. Outras foram subprodutos da guerra fria e da instabilidade política, como os regimes militares da América Latina, da África e da Ásia. E houve, também, ditaduras teológicas, erigidas sobre o fundamentalismo religioso, como o Irã dos aiatolás. A redenção democrática veio em duas ondas diversas ${ }^{59}$ : uma após a Segunda Guerra Mundial, com a reconstitucionalização de países como Alemanha, Itália e Japão; e a outra numa faixa de tempo que vai dos anos 70 aos anos 90, começando com a Revolução dos Cravos de 1974, em Portugal, passando pela redemocratização de diversos países da América Latina, na década de 80, como Brasil, Argentina e Uruguai, e chegando aos países da Europa Central e Oriental, como Hungria, Polônia e Romênia, após a dissolução da União Soviética, na década de 90, e também à África do Sul. Tendo disputado a primazia com diversos projetos alternativos - fascismo, comunismo, regimes militares, fundamentalismo islâmico - é legítimo afirmar que a democracia constitucional foi a ideologia vitoriosa do século $X^{60}$.

Nos últimos tempos, porém, alguma coisa parece não estar indo bem. Ao comentarem o período que se inicia em meados da primeira década do século XXI e vem até os dias de hoje, autores têm se referido a uma recessão democrática ${ }^{61}$ ou retrocesso democrático6 ${ }^{62}$. Os exemplos foram se acumulando ao longo dos anos: Hungria, Polônia, Turquia, Rússia, Geórgia, Ucrânia, Filipinas, Venezuela, Nicarágua. Em todos esses casos, a erosão da democracia não se deu por golpe de Estado, sob as armas de algum general e seus comandados. Nos exemplos acima, o

\footnotetext{
${ }^{58}$ Harari (2017, p. 73).

59 V. Huntington (1991, p. 12). Huntington foi o primeiro a utilizar a ideia de "ondas de democratização": a primeira onda teria ocorrido na primeira metade do século XIX, quando os países crescentemente foram adotando a ideia de sufrágio universal; a segunda se deu após o fim da Segunda Guerra Mundial; e a terceira a partir dos anos 70. O texto é anterior ao florescimento de democracias após o fim do modelo comunista.

${ }^{60}$ V. Barroso (2019). Ver também Ackerman (1997, p. 771-772). Escrito no final do século passado, assim anotou o autor: "A esperança iluminista em constituições escritas está varrendo o mundo" (tradução livre).

${ }^{61}$ Diamond (2015, p. 141).

${ }^{62}$ Huq e Ginsburg (2018, p. 78; 91 et seq.).
} 
processo de subversão democrática se deu pelas mãos de presidentes e primeirosministros devidamente eleitos pelo voto popular ${ }^{63}$. Em seguida, paulatinamente, vêm as medidas que pavimentam o caminho para o autoritarismo: concentração de poderes no Executivo, perseguição a líderes de oposição, mudanças nas regras eleitorais, cerceamento da liberdade de expressão, novas constituições ou emendas constitucionais com abuso de poder pelas maiorias, esvaziamento ou empacotamento das cortes supremas com juízes submissos, entre outras. O grande problema com a construção dessas democracias iliberais ${ }^{64}$ é que cada tijolo, individualmente, é colocado sem violação direta ao Direito vigente. O conjunto final, porém, resulta em supressão de liberdades e de eleições verdadeiramente livres e competitivas. Este processo tem sido caracterizado como legalismo autocrático ${ }^{65}$.

Por trás desse desprestígio corrente da democracia está um conjunto de eventos e de circunstâncias que assinalam o mundo contemporâneo: a globalização e seu impacto sobre o emprego e o nível salarial, as ondas de imigração, o terrorismo, as mudanças climáticas, o racismo, a debilidade e baixa representatividade dos partidos políticos, o fundamentalismo religioso, o movimento feminista, as conquistas dos grupos LGBT, em meio a muitos outros. A reação à soma desses componentes heterogêneos explica o avanço do populismo conservador na política de diferentes países do mundo, incluindo os Estados Unidos (Trump), a GrãBretanha (Brexit), a Europa Continental (Victor Orbán) e o Brasil (Bolsonaro). É possível sistematizar esses diferentes fatores em três categorias: políticas, econômico-sociais e culturais-identitárias ${ }^{66}$. As causas políticas estão na crise de representatividade das democracias contemporâneas, em que o processo eleitoral não consegue dar voz e relevância à cidadania. "Não nos representam", é o bordão da hora ${ }^{67}$. Em parte, porque a classe política se tornou um mundo estanque, descolado da sociedade civil, e em parte pelo sentimento de que o poder econômico-financeiro globalizado é que verdadeiramente dá as cartas ${ }^{68}$. Daí a ascensão dos que fazem o discurso anti-establishment, antiglobalização e "contra tudo isso que está aí".

As causas econômico-sociais estão no grande contingente de trabalhadores e profissionais que perderam seus empregos ${ }^{69}$ ou viram reduzidas as suas

\footnotetext{
${ }^{63}$ Levitsky e Ziblatt (2018, p. 03).

${ }^{64}$ Aparentemente, o termo foi utilizado pela primeira vez por Zakaria(1997, p. 22).

${ }^{65}$ Scheppele (2018, p. 545).

${ }^{66}$ Sobre os diferentes fatores que deflagraram a onda populista conservadora, v. Castells (2018); Inglehart e Norris (2016).

${ }^{67}$ V. Castells (2018, p. 103).

${ }^{68}$ Nesse sentido, v. Holmes (2018, p. 401): “[D]epois que o eleitorado vota, os mercados votam ou os bancos votam ou Bruxelas vota. A segunda série de votos é a que conta".

${ }^{69}$ Oliveira (2019).
} 
perspectivas de ascensão social ${ }^{70}$, tornando-se pouco relevantes ${ }^{71}$ no mundo da globalização, da nova economia do conhecimento e da automação, que enfraquecem as indústrias e atividades mais tradicionais ${ }^{72}$. Sem mencionar as políticas de austeridade pregadas por organizações internacionais e países com liderança econômica mundial ${ }^{73}$, que reduzem as redes de proteção social. Por fim, as causas culturais identitárias, que em alguma medida resultam também de um choque de gerações: há um contingente de pessoas de meia ou de mais idade que não professam o credo cosmopolita, igualitário e multicultural que impulsiona a agenda progressista de direitos humanos, igualdade racial, políticas feministas, casamento gay, defesa de populações nativas, proteção ambiental e descriminalização de drogas, entre outras modernidades. Estas pessoas, que se sentem desfavorecidas ou excluídas no mundo do "politicamente correto", apegam-se a valores tradicionais que lhes dão segurança e o sonho da recuperação de uma hegemonia perdida ${ }^{74}$. Há autores que afirmam haverem recolhido evidências no sentido de que o avanço do populismo se deve, sobretudo, às mudanças culturais que causaram a erosão de valores e costumes tradicionais das sociedades ocidentais ${ }^{75}$. Em alguns países, como foi o caso do Brasil -e, também, de outros da América Latina, da Ásia e mesmo da Europa -, adiciona-se a essa mistura já complexa a reação contra a corrupção estrutural e sistêmica, que frustrou as expectativas que recaíram sobre partidos tidos por progressistas, mas que não conseguiram escapar da força de gravidade dos velhos hábitos da velha política.

É cedo para concluir que a democracia esteja verdadeiramente decadente. Num mundo em transformação acelerada, é inevitável que ela passe por sobressaltos e adaptações. Os dois pilares das democracias liberais, tal como assentados pela Declaração dos Direitos do Homem e do Cidadão, de $1789^{76}$, já não são mais o que foram: (i) a separação de Poderes convive com a ascensão institucional das cortes constitucionais e do Poder Judiciário em geral; e (ii) os direitos fundamentais se expandiram para abrigar sufrágio universal, privacidade, igualdade de gênero e

\footnotetext{
70 Issacharoff (2018, p. 447): “A combinação da desaceleração econômica depois de 2008 e o impacto do comércio globalizado nos salários nos países industrializados avançados manchou a legitimidade dos regimes democráticos como um jogo interno, um meio de institucionalizar as prerrogativas da elite"; ver também Canzian (2019).

${ }^{71}$ V. Harari(2018, p. 34 et seq.).

72 Inglehart e Norris (2016, p. 02).

73 Trotman (2013) e Cerulus (2017).

${ }^{74}$ V. Castells (2018, p. 178): "A essa crise da representação de interesses se une uma crise identitária como resultante da globalização. Quanto menos controle as pessoas têm sobre o mercado e o seu Estado, mais se recolhem numa identidade própria que não possa ser dissolvida pela vertigem dos fluxos globais. Refugiam-se em sua nação, em seu território, em seu deus".

${ }^{75}$ Inglehart e Norris (2016, p. 30).

${ }^{76}$ Declaração dos Direitos do Homem e do Cidadão: "Art. 16. A sociedade em que não esteja assegurada a garantia dos direitos nem estabelecida a separação dos poderes não tem Constituição".
} 
racial, liberdade de orientação sexual e, em muitas partes do mundo, direitos sociais. Há, ainda, nos dias atuais, o fator China: um modelo alternativo autoritário, tisnado pela corrupção, mas de vertiginoso sucesso econômico e social. Enfim, um tempo de complexidades e perplexidades. Mas cabe aqui relembrar passagem célebre de Alex de Tocqueville, referindo-se à Revolução Francesa, mas com reflexão atemporal e universalizável: só se derruba um regime se ele já estiver corroído por dentro ${ }^{77}$.

Embora preocupante, é possível que o refluxo temporário do vigor democrático seja apenas o movimento pendular da vida e da história. E, também, não se deve descartar tratar-se de um momento de certa amargura do pensamento progressista devido à prevalência, na quadra atual, em muitas partes do mundo, de ideias conservadoras, pouco simpáticas às bandeiras ambientais, de gênero, cosmopolitas, multiculturais, feministas, pró-gays e populações indígenas. Mas assim é a democracia, mesmo: às vezes se ganha, às vezes se perde.

\section{O AQUECIMENTO GLOBAL}

A mudança climática tem sido identificada como o mais relevante problema ambiental do século XXI e uma das questões definidoras do nosso tempo ${ }^{78}$. Inúmeros autores têm se referido ao tema como "a tragédia dos comuns", significando uma situação na qual os indivíduos em geral, agindo com atenção apenas ao interesse próprio, comportam-se, na utilização de recursos escassos, de maneira contrária ao bem comum ${ }^{79}$. $\mathrm{O}$ tratamento das questões ambientais exige cooperação entre os diferentes países, porque os recursos naturais e os fatores que os afetam não respeitam fronteiras. Duas características do debate sobre o clima dificultam o seu equacionamento. A primeira é a existência de um misto de desconhecimento e ceticismo, aos quais se soma o custo econômico e político das providências necessárias. A segunda é que os efeitos das emissões somente serão suportados pelas próximas gerações, fato que funciona como um incentivo para se adiarem decisões que em rigor são urgentes. $O$ conceito central aqui ainda continua a ser o de "desenvolvimento sustentável", de longa data entendido como aquele que "atende às necessidades do presente, sem comprometer a possibilidade de as gerações futuras atenderem a suas próprias necessidades" ${ }^{80}$. Um dos objetivos do desenvolvimento sustentável, aprovado pela ONU em 2015, é precisamente o da "ação contra a mudança global do clima" 81 .

\footnotetext{
77 Elster (2011, p. 170-185).

${ }^{78}$ Harrison e Sundstrom (2010, p. ix). De acordo com o laureado com prêmio Nobel Nordhaus (2013, p. 11): "Global warming is one of the defining issues of our time".

79 Sobre o conceito de tragédia dos comuns ou, talvez, mais propriamente, tragédia dos bens comuns, v. Lloyd (1833), Hardin(1968, p. 1243) e Ostrom (1990).

${ }^{80}$ United Nations (1987).

81 United Nations (2019?a).
} 
O aquecimento global está diretamente associado ao denominado "efeito estufa". Efeito estufa é o processo natural de aquecimento da superfície da Terra. Quando a energia solar alcança a atmosfera terrestre, parte dela é refletida de volta para o espaço e parte é retida na atmosfera, pelos denominados gases estufa. Esses gases - de que são exemplos dióxido de carbono $\left(\mathrm{CO}_{2}\right)$, metano, óxido nitroso, ozônio e CFCs - aprisionam parte do calor irradiado pela Terra, impedindo que alcance o espaço. É essa energia absorvida que mantém o planeta aquecido, conservando a temperatura em níveis que permitem a existência de vida. $\mathrm{O}$ problema ora enfrentado é que as atividades humanas, com destaque para a queima de combustíveis fósseis (carvão, petróleo e gás natural), mas também agricultura, pecuária, desmatamento etc., têm aumentado significativamente a concentração dos gases estufa na atmosfera, aumentando a retenção de calor ${ }^{82}$. Este é o fenômeno que tem sido designado de aquecimento global. Em 1972, o Clube de Roma publicou um relatório seminal intitulado "Os Limites do Crescimento", no qual afirmava que a mudança climática era causada pelo dióxido de carbono $\left(\mathrm{CO}_{2}\right)$ e que poderia produzir impacto sobre o crescimento econômico. A partir daí a questão climática entrou no radar de diferentes países, despertando a preocupação de governos, organismos internacionais e cientistas.

Desde 1972, começando com a Conferência das Nações Unidas sobre o Meio Ambiente Humano, realizada em Estocolmo, a maior parte dos países do mundo passou a se reunir em sucessivas conferências, que produziram documentos e diretrizes relevantes, incluindo a Conferência das Nações Unidas sobre Meio Ambiente e Desenvolvimento, no Rio de Janeiro, em 1992, a Conferência e o Protocolo de Kyoto, de 1997, a Conferência das Nações Unidas sobre desenvolvimento sustentável, de 2012, conhecida como Rio+20, e a 21ª Conferência do Clima, de 2015, que resultou no Acordo de Paris. Todas essas reuniões, declarações e tratados tiveram por finalidade principal despertar a atenção mundial para a questão ambiental, introduzir o conceito de desenvolvimento sustentável e enfrentar o problema do aquecimento global, sobretudo pela limitação da emissão de gases que agravam o efeito estufa, notadamente o dióxido de carbono $\left(\mathrm{CO}_{2}\right)$. Em 1988, foi criado, no âmbito das Nações Unidas, o Painel Intergovernamental sobre Mudança Climática (Intergovernmental Panel on Climate Change - IPCC), com o propósito de fornecer informações científicas aos países acerca da mudança climática, de suas implicações e riscos potenciais, apresentando alternativas para a mitigação do problema e para as adaptações necessárias ${ }^{83}$. As conclusões do IPCC refletem o consenso científico global na matéria ${ }^{84}$.

\footnotetext{
${ }^{82}$ As informações técnicas desse parágrafo foram colhidas em Global climate change. Nasa (2019?) e Australian Government (2019?).

${ }^{83}$ United Nations (2019?b).

${ }^{84}$ United Nations (2019?c).
} 
Nos dias atuais, a grande maioria dos cientistas concorda que o processo de aquecimento global em curso é resultante da atuação do homem ${ }^{85}$. De acordo com o Quarto Relatório do Painel Intergovernamental sobre Mudança Climática, a ocorrência do aquecimento global é inequívoca e a probabilidade de que o responsável seja o homem é superior a $90 \%{ }^{86}$. A comunidade científica global tem endossado essa conclusão ${ }^{87}$. O tema, todavia, não é objeto de consenso. No plano político, líderes como Donald Trump e Jair Bolsonaro têm negado ou minimizado os riscos climáticos. Também na academia, estudiosos reconhecidos, embora aceitando que o homem contribui para o aquecimento global, rejeitam a urgência de políticas que enfrentem o problema ${ }^{88}$. Outros contestam os achados e as previsões do Painel Intergovernamental ${ }^{89}$ ou simplesmente negam que o aquecimento global seja causado pela atuação do homem. Para esses, o clima mundial sempre alternou ciclos, sendo o momento atual de aquecimento apenas uma de suas fases ${ }^{90}$. Para tornar o debate ainda mais convulsionado, há estudos demonstrando que grupos que se opõem à redução da produção de combustíveis fósseis utilizaram os meios de comunicação de massas para semear incertezas e reduzir o apoio às medidas contra as mudanças climáticas ${ }^{91}$. Nada obstante as posições e reações contrárias, o entendimento prevalecente é o de que a situação é grave, os riscos são reais e as providências devem ser tomadas com urgência.

Não é singela a tarefa de prever os impactos reais da mudança climática. E isso não apenas pelas incertezas que cercam os efeitos das emissões de gases estufa e dos ciclos climáticos, como também por ser difícil avaliar a capacidade de reação dos seres humanos e das demais espécies existentes na Terra ${ }^{92}$. Esse quadro de incerteza é agravado pelo que a literatura tem denominado climate lag: cientistas estimam que o impacto das emissões somente será plenamente sentido entre $25 \mathrm{e}$ 50 anos depois de sua ocorrência. É fora de dúvida, porém, que o Planeta está em fase de aquecimento e as consequências desse fenômeno já podem ser sentidas em diferentes partes do mundo ${ }^{93}$. Entre elas podem ser apontados o aumento da temperatura global, o aquecimento dos oceanos, o derretimento das calotas polares (ice sheets) na Groenlândia e na Antártida, a retração das geleiras (glacial retreat), a perda da cobertura de neve no Hemisfério Norte, a elevação do nível do mar, a

\footnotetext{
${ }^{85}$ Oreskes (2007).

${ }^{86}$ IPCC Summary for Policymakers.

${ }^{87}$ Oreskes (2007). Nesse artigo, a autora afirma haver um "consenso científico sobre mudança climática". Num levantamento de mais de 900 artigos escritos entre 1993 e 2003, nenhum deles negava quer o aquecimento global, quer a influência humana na mudança climática. Ver também: Sumi (2011).

${ }^{88}$ Lindzen (2006).

${ }^{89}$ Michaels (2004).

${ }^{90}$ Singer (2007).

${ }^{91}$ Gelbspan (1997). Ver também, Corbett e Durfee (2004, p. 129).

${ }^{92}$ Nordhaus (2013, p. 49 et seq.).

${ }^{93}$ Na França, por exemplo, de acordo com a Météo France, a temperatura média em mais de 70 cidades subiu entre $2^{\circ}$ e $3^{\circ} \mathrm{C}$. V. Breteau (2018?).
} 
perda na extensão e espessura do gelo do Mar Ártico, a extinção de espécies e o número crescente de situações climáticas extremas (como furacões, enchentes e ondas de calor $)^{94}$. Na Amazônia, maior repositório de biodiversidade e maior armazenador de carbono do mundo, a área original da floresta foi reduzida em escala grandiosa e, ainda hoje, é afetada gravemente por atividades como agricultura, pecuária, exploração de madeira e garimpo, dentre outras. Existe risco real de morte da floresta em futuro não muito distante ${ }^{95}$. Há quem preveja que a mudança climática possa prejudicar a produção mundial de alimentos e as reservas de água ${ }^{96}$.

\section{Parte III}

\section{OS DESAFIOS DO NOSSO TEMPO: LIMITES E POSSIBILIDADES DO DIREITO}

\section{AlgunS RISCOS DA REVOLUÇão TECNOLÓGICA}

"O futuro é uma corrida entre o poder crescente da tecnologia e a sabedoria com a qual a usamos. Vamos nos certificar de que a sabedoria vença". Stephen Hawking

A Revolução digital e os desenvolvimentos que anunciam a $4^{\underline{a}}$ Revolução Industrial - com a sinergia entre tecnologia da informação e biotecnologia - trazem os fascínios da vida moderna e as promessas de longevidade e novos confortos. Com elas vêm, também, inconveniências, ameaças e perigos reais para a vida civilizada e a condição humana, que incluem novas táticas de guerra, como os ataques cibernéticos ${ }^{97}$. $\mathrm{O}$ direito precisa lidar com desafios que testam os seus limites e suas possibilidades. A seguir, uma reflexão sobre alguns deles.

A internet e as redes sociais, por exemplo, deram lugar a desvios como discursos de ódio e campanhas de desinformação. Como proteger a comunicação no mundo das fake news e do deep fake, no qual vídeos falsos reproduzem imagem e voz de pessoas reais em situações inusitadas e inverídicas? As empresas que oferecem plataformas para as mídias digitais, compreensivelmente, relutam em funcionar como censores privados. Por outro lado, a interferência estatal no domínio da liberdade de expressão é sempre arriscada. Diante desse quadro, não há remédios jurídicos totalmente eficientes ou politicamente simples. Outro ponto importante diz respeito à dominação de mercados e à concentração de poder econômico e

\footnotetext{
${ }^{94}$ Hansen et al. (2016, p. 3761). Ver também, Nasa (2019?), Miller e Fox (2019).

${ }^{95}$ Vergara (2011).

${ }^{96}$ Cohen e Waddell (2009, p. 04) e Flavelle (2019).

${ }^{97}$ Vishwanath (2019).
} 
político em algumas poucas empresas ${ }^{98}$. Reguladores em todo o mundo têm se voltado para esse problema ${ }^{99}$. A riqueza, que antes se acumulava na propriedade da terra e dos meios de produção, hoje se transferiu para a propriedade de dados. Sua regulação adequada, portanto, é imprescindível para impedir a concentração de riqueza e poder nas mãos de uma pequena elite ${ }^{100}$. Ainda no campo da justiça distributiva, surge, igualmente, a questão da tributação justa das grandes empresas de tecnologia, frequentemente acusadas de evasão fiscal ${ }^{101}$.

De todas as vicissitudes trazidas pelos avanços tecnológicos, os riscos para a privacidade têm sido uma das principais preocupações da sociedade e das autoridades governamentais. No seu núcleo essencial, privacidade significa a existência de uma esfera na vida de todo indivíduo protegida contra a invasão por outros indivíduos, empresas ou pelo Estado ${ }^{102}$. Desde seu reconhecimento inicial, em meados do século passado ${ }^{103}$, até os dias de hoje, o contexto em que se manifesta o direito de privacidade variou enormemente. No momento atual, uma das dimensões mais complexas da privacidade envolve o uso da tecnologia, no mundo da internet e das redes sociais. Nesse cenário, há duas situações diversas a considerar: (i) a identificação pessoal do usuário, que inclui informações como nome, endereço, estado civil, ocupação, dados financeiros, declarações ao Fisco etc; e (ii) informações sobre comportamentos, preferências, interesses e preocupações de cada pessoa, obtidas a partir da navegação online. A internet é alimentada, em grande parte, pela exploração desses dados e o controle sobre eles se tornou uma das questões vitais do nosso tempo.

Episódios diversos de uso indevido de informações deflagraram reações de organismos internacionais, regionais e de governos locais para disciplinar o uso das informações e o direito de privacidade. O escândalo mais rumoroso eclodiu em março de 2018, envolvendo a Cambridge Analytica, uma empresa de consultoria política que operou em diversas campanhas eleitorais e foi acusada de ter adquirido e utilizado dados pessoais de 87 milhões de usuários do Facebook, obtidos de um

\footnotetext{
98 A esse propósito, confira-se o contundente artigo do cofundador do Facebook, defendendo a limitação do seu poder econômico, que inclui, também, o controle do Instagram e do Whatsapp. V. Hughes (2019).

${ }^{99}$ E.g., Tracy (2019); Waters, Bond e Murphy (2019).

100 V. Harari (2018, p. 77; 80) e Risse (2018, p. 11).

${ }^{101}$ Inman (2019), Hill, Khan e Waters (2018) e Mckay (2019).

102 Nos Estados Unidos, a ideia de privacidade, como assentada em casos como Griswold v. Connecticut, 381 U.S. 479 (1965), e Roe v. Wade, 410 U.S. 113 (1973), envolve questões que, em outras jurisdições constitucionais, são tratadas no âmbito das liberdades individuais e da igualdade.

103 Atribui-se ao célebre artigo de Warren e Brandeis (1890, p. 193), a primeira referência a este direito. No texto, citando o Juiz Thomas Cooley, os autores se referiram ao direito de privacidade como o "direito de ser deixado em paz" (the right to be let alone). Na jurisprudência americana, ele só veio a ser fundamento expresso de uma decisão no caso Griswold v. Connecticut, referido acima (381 U.S. 479). O direito de privacidade é hoje explicitamente reconhecido na Constituição de 181 países. V. Constitute Project (2019?).
} 
pesquisador externo que, alegadamente, os recolhia para fins acadêmicos ${ }^{104}$. Desde 2013, a Organização para a Cooperação e o Desenvolvimento Econômico (OCDE) havia revisado suas Privacy Guidelines para adaptá-las às "mudanças tecnológicas, aos mercados, ao comportamento dos usuários e à crescente importância das identidades digitais". Já a União Europeia editou a General Data Protection Regulation (GDPR), que entrou em vigor em 25 de maio de 2018, cuja essência é assegurar a soberania de cada indivíduo sobre os dados que lhe dizem respeito, com direito de acesso e de retificação, bem como a exigência de prévio consentimento para o seu uso. $\mathrm{O}$ documento, com 99 artigos, cuida, também, em meio a múltiplos temas, do controvertido direito ao esquecimento e de normas sobre a proteção da concorrência. Nos Estados Unidos, seguindo os passos da União Europeia, o Estado da Califórnia aprovou o California Data Privacy Protection Act, em vigor a partir de $1^{\circ}$ de janeiro de 2020. No Brasil, quarto país do mundo em número de usuários da internet, com 181 milhões ${ }^{105}$, foi aprovada em 2018 a Lei Geral de Proteção de Dados, com vigência prevista para agosto de 2020.

Questões ainda mais intrincadas, no plano jurídico e no plano ético, envolvem os avanços da biotecnologia. Por exemplo: desde que a ovelha Dolly foi clonada, em 1996, o tema da clonagem humana tem sido objeto de intenso debate entre juristas, cientistas e eticistas em todo o mundo. A despeito de diversos esforços de elaboração de uma convenção internacional banindo a clonagem humana, não se chegou a um consenso. Em 2005, a ONU aprovou uma declaração, considerada ambígua ${ }^{106}$, banindo a clonagem "na medida em que incompatível com a dignidade humana e com a proteção da vida humana"107. A declaração não tem caráter vinculante. A maioria dos países do mundo, todavia, proíbe expressamente a clonagem para fins reprodutivos, embora alguns a admitam com propósito terapêutico ${ }^{108}$. O comércio de órgãos humanos é igualmente proibido pela quase totalidade dos países, embora seja grave, em muitas partes do mundo, o fenômeno do tráfico de órgãos ${ }^{109}$. Esse tema deverá sofrer, em breve, o impacto dos avanços

\footnotetext{
${ }^{104}$ Confessore (2018).

${ }^{105}$ Rodrigues (2018). O Brasil só fica atrás da China, da Índia e dos Estados Unidos.

106 V. Langlois (2017, p. 17019).

107 United Nations (2005).

${ }^{108}$ Sobre a diferença entre ambas as modalidades de clonagem: "A clonagem reprodutiva envolve a criação de um animal que é geneticamente idêntico a um animal doador através da transferência nuclear de células somáticas. Na clonagem reprodutiva, o recém-criado embrião é colocado de volta no ambiente uterino, onde pode se implantar e se desenvolver. (...) Na clonagem terapêutica, um embrião é criado de maneira semelhante, mas as células "clonadas" resultantes permanecem em um prato no laboratório; eles não são implantados no útero de uma mulher" (tradução livre). What is the difference between reproductive and therapeutic cloning?. New York State (2019?). ${ }^{109}$ Wikipedia (2019?) e Moorlock (2018).
} 
da medicina regenerativa e a perspectiva da produção de tecidos humanos em laboratório ${ }^{110}$.

Especialmente delicado é o tema da engenharia genética, expressão que identifica diferentes métodos de manipulação ou modificação dos genes de um determinado organismo, com o fim de aprimorá-lo ou de criar novos organismos. A biotecnologia aqui tem o potencial de remodelar a vida e alterar a própria natureza do humano, fato que, naturalmente, mexe com os valores éticos e as crenças religiosas das pessoas. Há quem preveja que o próprio homo sapiens, com suas características essenciais, vai desaparecer ${ }^{111}$. Cientistas, em geral, revelam ceticismo quanto à eficácia de leis que venham a proibir o uso de engenharia genética, não por acharem-na necessariamente positiva, mas por acreditarem ser impossível evitá-la. Em primeiro lugar, pelo apelo óbvio do seu uso para o tratamento de doenças que possam ser curadas pela correção de mutações de genes. Porém, e muito mais perigoso, pela tentação de aprimorar características humanas, como o tamanho da memória, a resistência a doenças e o prolongamento da vida ${ }^{112}$. Daí surgiriam super-homens empoderados pela biotecnologia e pelos algoritmos, que constituiriam uma elite, com todos os riscos de incremento da desigualdade e do exercício de opressão sobre os demais humanos comuns ${ }^{113}$.

Por fim, cabe uma reflexão sobre Inteligência Artificial, cujo avanço vertiginoso vai permitindo a transferência de atividades e capacidades decisórias tipicamente humanas para máquinas que são alimentadas com dados, estatísticas e informações. No estágio atual, máquinas não têm ideias próprias nem discernimento do que seja certo ou errado ${ }^{114}$. Vale dizer: a inteligência artificial depende inteiramente da inteligência humana que a alimenta, inclusive, com valores éticos. As utilidades da inteligência artificial são incomensuráveis e vão desde robôs que realizam com maior precisão cirurgias delicadas até carros autônomos que causam muito menos acidentes do que os dirigidos por seres humanos. Os riscos também são elevados, alguns imediatos e outros de longo prazo. Entre os que já representam uma ameaça contemporânea está o desaparecimento de empregos, com a substituição de trabalhadores humanos por máquinas, com a exclusão social dos que já não têm mais condições de se adaptar

\footnotetext{
${ }^{110}$ De acordo com o sítio Nature Research, medicina regenerativa "é o ramo da medicina que desenvolve métodos para regenerar, reparar ou substituir células, órgãos ou tecidos danificados ou doentes. A medicina regenerativa inclui a geração e o uso de células-tronco terapêuticas, a engenharia de tecidos e a produção de órgãos artificiais" (tradução livre).

${ }^{111}$ Harari (2018, p. 121-122).

112 Hawking $(2018$, p. 81; 195).

${ }^{113}$ Harari (2018, p. 75).

114 Winston (2018), gentilmente enviada pelo autor, p. 02: “Eles (os programas) não percebem como nós e não pensam como nós; na verdade, eles não pensam nada". Para uma visão diferente nessa matéria, v. Kaplan (2016, p. 69-88).
} 
às novas demandas do mercado ${ }^{115}$ e que ficarão desprovidos de perspectivas e de poder político ${ }^{116}$. Em segundo lugar, num mundo em que a inteligência artificial já está sendo utilizada por diversos tribunais, há o temor de que possa reforçar preconceitos e discriminações, na medida em que os computadores sejam alimentados com os valores, sentimentos e impressões dominantes na sociedade ${ }^{117}$.

Os perigos de longo prazo são ainda mais alarmantes. Em primeiro lugar, a própria democracia liberal - que se funda na liberdade individual e na autonomia da vontade - é posta em questão. De fato, a partir do momento em que as grandes decisões para a vida de cada um (ou para a sociedade como um todo) forem mais eficientemente tomadas por uma vontade externa, heterônoma, o livre-arbítrio, um dos pilares do liberalismo estará comprometido ${ }^{118}$. Ademais, é preciso considerar a ameaça de que, no futuro, computadores possam efetivamente desenvolver inteligência própria - que seria, segundo Stephen Hawking, "o maior evento da história humana" -, passarem a ter vontade autônoma e saírem do controle humano ${ }^{119}$. O temor parece enredo de filme de ficção científica, mas a advertência vem de cientistas reconhecidos mundialmente ${ }^{120}$. No fundo, tudo se resumirá a saber quem controlará quem.

\section{A DEMOCRACIA E SEUS INIMIGOS INTERNOS}

"A democracia é feita de promessas, decepções e administração da decepção". Stephen Holmes ${ }^{121}$

Como assinalado, as democracias contemporâneas enfrentam problemas que resultam de causas variadas, decorrentes de inovações tecnológicas, transformações sociais e mudanças nos costumes. Os três Poderes do Estado enfrentam juízos e sentimentos que incluem desconfiança, disfuncionalidade e ineficiência. A seguir, uma breve reflexão acerca de três fatores que colocam em xeque as democracias contemporâneas: o arrefecimento do sentimento democrático dos cidadãos, a desigualdade e a corrupção. Os dois primeiros fatores são mundiais e afetam mesmo os países mais desenvolvidos. O terceiro, embora presente em

${ }^{115}$ Para um minucioso estudo do impacto da computadorização sobre o emprego, v. Frey e Osborne (2013).

116 Risse (2018, p. 02). Como anota Harari (2018, p. 08-09), as massas trabalhadoras, que antes temiam a exploração, agora temem a irrelevância.

117 V. Risse (2018, p. 10). Ver também: Lohr (2019).

${ }^{118}$ Harari, 2018, p. 55-56.

119 É o que se denomina "singularidade": a ideia de que em algum momento máquinas vão se tornar inteligentes, se autodesenvolverem e escapar de controle. V. Kaplan, 2016, p. 138.

${ }^{120}$ Hawking (2018, p. 184-186).

${ }^{121}$ Stephen (2017). 
graus variados em escala global, é causa dramática de atraso de países emergentes, da América Latina à Ásia, da África aos países da Europa Central e Oriental.

No tocante ao arrefecimento do sentimento democrático, pesquisas em diferentes partes do mundo revelam a perda de prestígio dos governos fundados na soberania popular ${ }^{122}$. A democracia já viveu dias mais efusivos. O direito público - tanto o direito constitucional como o direito administrativo - precisará investir energia na busca por um desenho institucional capaz de reavivar as instituições democráticas e de mobilizar a cidadania para renovar a crença nas ideias que iniciaram sua trajetória na Revolução Inglesa de 1689 e viveram um momento de apogeu na virada do século XX para o XXI: Estado de direito, governo da maioria, limitação do poder, respeito aos direitos fundamentais e livre-iniciativa. Tais inovações hão de passar por uma revisita ao modelo de separação de Poderes - concebido para um mundo pós-medieval e pré-Revolução Industrial -, por uma revisão profunda das formas de representação política e por mecanismos mais eficientes de governança, não apenas no Executivo, mas também no Legislativo e no Judiciário.

A difusão do acesso à internet gerou a expectativa de mais participação política, melhor governança e maior accountability dos governantes em geral. Imaginou-se que no mundo interconectado por computadores seria possível a criação de uma abrangente esfera pública digital capaz de viabilizar o exercício da democracia deliberativa, fundada num debate público amplo entre pessoas livres e iguais, com oferecimento de razões e prevalência do melhor argumento ${ }^{123}$. Na vida real, porém, verificou-se certa frustração dessas expectativas: até aqui, a internet não encorajou um diálogo racional sobre matérias de interesse coletivo, mas, ao revés, fomentou a tribalização, em que grupos com opinião formada - e muitas vezes radicais - falam para si próprios ${ }^{124}$. Sem mencionar as campanhas de desinformação, com circulação deliberada de notícias falsas, assim como discursos de ódio. Não se deve, todavia, generalizar essa percepção da internet como um espaço de inexorável polarização de grupos incapazes de interagir construtivamente. Não apenas é possível acreditar em um avanço civilizatório paulatino rumo a uma maior racionalidade e tolerância, como também já existem experiências positivas de sua utilização, como os

122 Foa e Mounk (2016, p. 08): “Apenas um em cada três millennials holandeses (i.e., os nascidos desde 1980) atribui a máxima importância a viver em uma democracia; nos Estados Unidos, esse número é um pouco menor, cerca de $30 \% "$. Pesquisa do Latinobarómetro revela que o apoio à democracia na América Latina caiu para 48\% em 2018. O apoio máximo foi de 63\%, em 1997. V. Latinobarómetro (2019).

${ }^{123}$ Democracia deliberativa é uma expressão guarda-chuva que comporta inúmeras variações. Sobre o tema, v., especialmente, Habermas (1997). Para outros enfoques, v., exemplificativamente, Cohen 1997, p. 67-91), Pettit (2003, p. 138-162), Gutmann (2004, p. 125-138), Ackerman (2002, p. 129) e Mansbridge (2003).

124 Sobre a "polarização de grupos" e o surgimento de "enclaves deliberativos", v. os seguintes escritos: Sunstein (2008, p. 87-95) e Boston Review (2001). Ver também: Holmes (2018, p. 401): “Mas a extraordinária proliferação de plataformas de mídia produziu uma caricatura distorcida do pluralismo, fragmentando o espaço político em fortalezas ideológicas mutuamente isoladas entre as quais nenhuma comunicação séria é possível". 
processos constituintes digitais do Chile ${ }^{125} \mathrm{e}$ da Islândia ${ }^{126}$, a prática de governança digital na Estônia ${ }^{127}$ ou de orçamentos participativos em cidades como Berlim, Lisboa e Porto Alegre, entre outras ${ }^{128}$. Em suma: o fato de a internet, em uma avaliação no atacado, não ter conseguido, até agora, converter participação social em deliberação de qualidade - e com isso fomentar os objetivos democráticos - não justifica o abandono das possibilidades construtivas que ela oferece ${ }^{129}$.

A desigualdade, por sua vez, é a marca dramática do nosso tempo, a agenda inacabada do processo civilizatório. A desigualdade que merece estigma não é a que privilegia o talento, o conhecimento adquirido ou o trabalho aplicado. Mas, sim, aquela que nega igualdade de oportunidades às pessoas, gerando incluídos e excluídos, e impedindo o acesso equiparado aos bens da vida, dentre os quais educação, saúde e condições existenciais mínimas. Trata-se da desigualdade que reforça e reproduz as situações de pobreza, como, por exemplo, sistemas tributários que concentram renda em lugar de redistribuí-la e políticas públicas que favorecem os extratos dominantes da sociedade. A ideia de democracia traduz um projeto comum de autogoverno, em que todos devem se sentir participantes e ter um sentimento de pertencimento. Se as pessoas se sentem excluídas, elas abandonam o projeto. É isso que muitas pesquisas de opinião têm revelado. É fato que o mundo chegou ao início do século XXI muito mais igual do que iniciara o século XX. Porém, a despeito do impacto positivo da globalização e dos avanços tecnológicos sobre a pobreza mundial, os dados documentam que, sobretudo a partir de 1980, houve um aumento na concentração de renda, tanto entre países como dentro de cada país ${ }^{130}$.

Em livro de grande sucesso desde o lançamento da versão em inglês, em 2014, Thomas Piketty procurou demonstrar que a desigualdade não é um acidente, mas uma característica do modo de produção capitalista, que só a intervenção do Estado pode conter ${ }^{131}$. Na obra ele reconhece que, nas sociedades de livre mercado, os incentivos ao conhecimento e à capacitação individual permitem uma maior

\footnotetext{
${ }^{125}$ Ford Foundation (2018, p. 19-32).

${ }^{126}$ Landemore (2015, p. 166).

127 Hinsbert, Jonsson e Karlsson (2013, p. 17-29).

${ }_{128}$ Rocke (2014), Allegretti, Dias e Antunes (2016, p. 148) e Prefeitura de Porto Alegre (2019?).

${ }^{129}$ Sobre o tema, v. Cavallazzi (2019).

${ }^{130}$ Neate (2017). A informação consta do Global Wealth Report, elaborado pelo Banco Credit Suisse, e refere-se ao ano de 2017. O quadro não se alterou no Global Wealth Report de 2018. Mais assustador, ainda: as 62 pessoas mais ricas do mundo somadas têm mais riqueza do que os 3,6 bilhões mais pobres. V. Harari (2017, p. 352). Esse dado, todavia, não pode ser inteiramente generalizado. V. Hasell (2018): "É um erro pensar que a desigualdade está aumentando em todos os lugares. Nos últimos 25 anos, a desigualdade aumentou em muitos países e caiu em muitos outros. É importante saber isso. Isso mostra que a crescente desigualdade não é onipresente, nem inevitável diante da globalização, e sugere que políticas e políticas no nível de países individuais podem fazer a diferença".

${ }^{131}$ Piketty (2014, p. 01).
} 
igualdade. Porém, aponta o que denomina uma contradição central do capitalismo e não uma imperfeição do mercado: o fato de que a taxa de retorno médio do capital (lucros, dividendos, juros, aluguéis) é, na maior parte da história, superior à taxa de crescimento da economia. Isso significa que a riqueza acumulada no passado cresce mais rapidamente do que a produtividade e os salários. Nesse ambiente, empreendedores se tornam rentistas e dominam os que detêm apenas a força de trabalho ${ }^{132}$. Retorna-se, assim, segundo ele, ao "capitalismo patrimonial", em que boa parte da economia é dominada pela riqueza herdada, ou, como escreveu Paul Krugman, "o berço conta mais do que esforço e talento"133. Embora o diagnóstico que apresenta, baseado em dados substanciais, tenha merecido adesão entusiástica de muitos ${ }^{134}$, a solução que propõe - instituição de um imposto anual de até $2 \%$ sobre o capital - despertou inúmeras críticas ${ }^{135}$. Outros autores defendem, como remédios mais eficientes contra a pobreza e a desigualdade, gastos sociais, como educação e saúde, e programas de renda mínima universal (universal basic income $)^{136}$.

Por fim, a corrupção produz consequências de naturezas diversas, todas elas capazes de comprometer os valores da democracia, minando sua credibilidade entre os cidadãos. Não por acaso, ao longo da história, inúmeros golpes de Estado e quebras da legalidade constitucional se deram em nome ou a pretexto do combate à corrupção. A corrupção tem custos econômicos, sociais e morais. Não é fácil medir com precisão os custos econômicos, que se materializam no desvio de recursos e, mais grave ainda, em decisões erradas e ineficientes, tomadas para atender interesses pessoais ou particulares ${ }^{137}$. Os custos sociais são igualmente visíveis: dinheiros desviados ou destinados a obras faraônicas e desnecessárias fazem falta para a saúde, para a educação, para a recuperação de estradas ou para melhorar a mobilidade urbana. Os custos morais são enormes e irreversíveis: cria-se uma cultura de extorsão, propina e desonestidade geral que abala a autoestima da sociedade e incentiva comportamentos desviantes em todos os níveis.

Boa parte das nações do mundo, inclusive entre as que hoje são mais desenvolvidas, enfrentaram, em algum momento de sua história, o círculo vicioso da corrupção ${ }^{138}$. Nesse domínio, o papel do Direito e dos tribunais é decisivo. Interessantemente, embora o problema seja tão antigo quanto a humanidade, a corrupção somente passou a ser vista como uma questão grave nas últimas décadas do século passado. No plano do direito internacional foi aprovada, em 17.12.1997, em Paris, a Convenção sobre o Combate à Corrupção de Funcionários Públicos

\footnotetext{
132 Piketty (2014, p. 25; 571-573).

133 Krugman (2014).

134 Cooper (2014).

135 E.g., Acemoglu e Robinson (2015, p. 03).

136 V. Pinker (2018, p. 108-110; 119). Ackerman, Alstot e Van Parijis (2006). O tema, todavia, não é pacífico. V. OECD (2017). Em linha severamente crítica, v. Acemoglu (2019).

137 Sobre o tema, v. Pinotti (2019).

${ }^{138}$ Um dos estudos mais completos sobre o tema é de Rose-Ackerman e Palifka (2016).
} 
Estrangeiros em Transações Comerciais Internacionais, sob os auspícios da OCDE ${ }^{139}$. Pouco à frente, em 15 de novembro de 2000, foi adotada, em Nova York, a Convenção das Nações Unidas contra o Crime Organizado Transnacional, com regras específicas sobre a criminalização da corrupção e da lavagem de dinheiro. Por fim, em 15 de novembro de 2003, foi adotada a Convenção das Nações Unidas Contra a Corrupção, com texto analítico e medidas amplas para enfrentamento do problema. No plano doméstico, a busca por integridade e o combate à corrupção têm como marco histórico o Foreign Corrupt Practices Act - FCPA, editado nos Estados Unidos em 1977. No Reino Unido, na mesma linha do FCPA, o UK Bribery Act - UKBA, de 2010, considerou crime o pagamento ou recebimento de propinas para/por agentes públicos. Diversos países da Europa, como Alemanha, Portugal, Espanha e outros possuem leis ou dispositivos legais impondo regras de compliance. No Brasil, em meio a dramáticos escândalos de corrupção por agentes públicos, foram aprovadas inúmeras inovações legislativas de combate à corrupção.

Mais recentemente, em diversos países, juízes e tribunais passaram a tratar os crimes de colarinho branco e a corrupção como delitos graves, punindo-os adequadamente. Em boa parte dos países emergentes, elites extrativistas se protegiam com a edição de leis que minimizavam os crimes que seus integrantes pudessem cometer, além da cooptação que praticavam em relação ao próprio Judiciário ${ }^{140}$. Leis agravando penas dos crimes de corrupção, combatendo a lavagem de dinheiro, regulamentando a colaboração premiada, disciplinando com mais rigor o financiamento eleitoral e impondo regras mais estritas em matéria de compliance começam a se multiplicar em países até pouco tempo devastados pela corrupção.

Como visto, o fenômeno global de recessão da democracia, com a ascensão de líderes autoritários e populistas, tem inúmeras causas, diretas e indiretas, dentre elas, o arrefecimento do sentimento democrático dos cidadãos, a desigualdade persistente e a elevada percepção de corrupção ${ }^{141}$. O Direito, sozinho, não conseguirá oferecer respostas eficientes para lidar com esses problemas. Isso, porém, não significa que não há nada a ser feito frente às ameaças iliberais. As cortes constitucionais, por exemplo, podem funcionar como importantes pontos de veto, bloqueando tentativas de restrição ilegítima de liberdades públicas, de

\footnotetext{
${ }^{139}$ De acordo com o Preâmbulo da Convenção, a corrupção "desperta sérias preocupações morais e políticas, abala a boa governança e o desenvolvimento econômico, e distorce as condições internacionais de competitividade".

${ }^{140}$ Para dar um exemplo emblemático, a legislação brasileira prevê a extinção da punibilidade, em caso de sonegação, mesmo que o pagamento do tributo se dê após a condenação criminal definitiva. Vale dizer: a sonegação é uma aposta de baixo risco.

${ }^{141}$ O Índice de Percepção da Corrupção é um indicador de corrupção no setor público calculado desde 1995 pela Transparência Internacional, entidade não governamental sediada em Berlim, na Alemanha. Em 2018, a Dinamarca estava na melhor colocação, Reino Unido e Alemanha

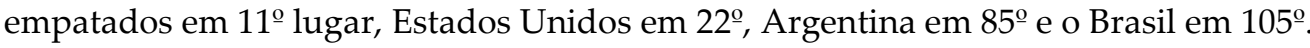


enfraquecimento do estado de direito e da concentração de poderes ${ }^{142}$. Além disso, o sistema jurídico pode atuar para tornar os partidos e as instituições políticas mais responsivas às demandas dos cidadãos. Para isso, em primeiro lugar, sistemas eleitorais precisam ser repensados para se tornarem mais inclusivos $\mathrm{e}$ representativos. Em segundo lugar, devem ser desenvolvidos mecanismos de participação democrática direta, com o uso de Tecnologias da Informação e Comunicação (TICs), abrindo caminho para a e-democracia ${ }^{143}$.

Em relação à desigualdade - da qual decorre, em boa medida, o problema da violência - há diversos papéis que o Direito pode desempenhar. Uma medida importante é a criação e o reforço de políticas de ação afirmativa para ampliar o acesso de pessoas hipossuficientes e de minorias à educação e ao mercado de trabalho. Além disso, o direito pode oferecer soluções para a melhoria da qualidade e da transparência dos gastos públicos, mediante instrumentos de controle e de monitoramento por parte da sociedade civil. Outra solução é o aperfeiçoamento do sistema tributário, tornando-o menos regressivo, diminuindo o peso que em muitos países se dá à tributação sobre o consumo e, em contrapartida, aumentando a participação da tributação sobre o patrimônio e renda. Em relação à corrupção, a repressão criminal séria e eficaz é, sem dúvida, importantíssima. No entanto, devese investir especialmente em salvaguardas de caráter preventivo, com a adoção de programas de integridade nas gestões pública e empresarial, bem como com a imposição de deveres de imparcialidade, neutralidade e transparência.

\section{OS ESFORÇOS CONTRA O AQUECIMENTO GLOBAL}

"O desespero eu aguento. O que me apavora é essa esperança". Millôr Fernandes

Como assinalado anteriormente, a mudança climática constitui um problema grave e real, e a responsabilidade principal por sua ocorrência recai sobre as atividades humanas. A principal causa do aquecimento global é a emissão de gases com efeito estufa, notadamente o dióxido de carbono $\left(\mathrm{CO}_{2}\right)$, proveniente, sobretudo, da produção e utilização de energia a partir de combustíveis fósseis, assim como do modo como se usa o solo. De forma mais analítica, isso significa o conjunto de atividades ligadas a indústria, transporte, agricultura, agropecuária, deflorestamento e manuseio do lixo, para citar algumas das mais relevantes. $\mathrm{O}$

\footnotetext{
${ }_{142}$ No Brasil, por exemplo, entre final de 2018 e ao longo de 2019, houve decisões importantes do Supremo Tribunal Federal derrubando restrições à liberdade de expressão nas universidades, impedindo a extinção de órgãos de proteção de direitos humanos por via de decreto e criminalizando a homofobia.

143 A esse propósito, já existem algumas ideias inovadoras, como, e.g., deliberative polling, crowdsourcing e minipublics. V. Fishkin (2003, p. 128), Medium (2016) e Fung (2011, p. 183-202).
} 
fenômeno tem natureza global e a emissão desses gases afeta toda a atmosfera, independentemente do ponto geográfico em que ocorra. Por isso mesmo, as soluções para o enfrentamento do aquecimento global precisam ser buscadas nas esferas global, regional, nacional e local. Além disso, necessitam não apenas da atuação de organismos internacionais e governos, mas também da conscientização de indivíduos e empresas. No plano dos comportamentos individuais e empresariais, há inúmeras recomendações de cientistas, entidades e organizações ambientais com medidas que vão desde evitar o desperdício de água até o plantio de árvores, passando pela utilização de fontes de energia renovável (como solar e eólica), o emprego de lâmpadas LED que consomem menos energia, a opção por aparelhos como geladeiras, condicionadores de ar ou máquinas de lavar que sejam "energia eficientes" e de carros "combustível eficientes". Além da mudança de hábitos alimentares e menor utilização de transporte individual.

Embora comportamentos sociais voluntários de consciência ambiental sejam importantes, é evidente que não são suficientes. O Direito, com sua força normativa e seus mecanismos de incentivos e sanções, há de desempenhar um papel decisivo no tratamento do tema. Algumas das principais iniciativas no tocante ao aquecimento global tiveram origem no direito internacional, a começar pela Convenção-Quadro das Nações Unidas sobre Mudança Climática, que é de 1992. A Convenção teve como objetivo "estabilizar as concentrações de gases estufa na atmosfera em um nível que previna perigosas interferências antropogênicas (i.e., causadas pela ação humana) com o sistema climático". A Convenção-Quadro, que entrou em vigor em 1994 e foi ratificada por 197 países, estabeleceu princípios abrangentes, obrigações de caráter geral e processos de negociação, a serem detalhados em conferências posteriores entre as partes. É de se notar o seu caráter avançado e premonitório, já que elaborada e ratificada em uma época em que ainda havia maior grau de incerteza científica sobre o tema. A ela se seguiram dois diplomas internacionais que a implementaram, completando o regime jurídico das Nações Unidas sobre mudança climática: o Protocolo de Kyoto e o Acordo de Paris.

O Protocolo de Kyoto foi concluído em 11 de dezembro de 1997. Seu processo de ratificação, todavia, foi bastante complexo, só vindo a entrar em vigor em 16 de fevereiro de 2005. Atualmente, 192 países aderiram a ele. O Protocolo procurou concretizar os objetivos da Convenção-Quadro instituindo o compromisso dos países em limitar e reduzir a emissão de gases estufa. No seu Anexo B, o Protocolo de Kyoto instituiu metas específicas de redução a serem alcançados por 36 países industrializados e a União Europeia, considerados os principais responsáveis por causarem o aquecimento global. Os países em desenvolvimento ficaram de fora dessa obrigação específica, com base no princípio da "responsabilidade comum, mas diferenciada e respectivas capacidades institucionais". O Protocolo previu, ainda, alguns mecanismos de mercado para a realização dos seus objetivos, baseados na comercialização de licenças de emissão. Três deles merecem referência expressa. O primeiro é o Sistema de Negociação de Emissões da União Europeia 
(EU Emission Trading Scheme - ETS), que é um exemplo do que se denomina "cap and trade system": as empresas têm um limite máximo de emissões, mas não o atingindo podem comercializar a diferença para empresas que excederam o seu limite ${ }^{144}$. O segundo é o Mecanismo de Desenvolvimento Limpo (Clean Development Mechanism - CDM), pelo qual países desenvolvidos investem em países em desenvolvimento em troca de créditos para suas emissões ${ }^{145}$. O terceiro é a Redução de Emissões por Deflorestamento ou Degradação Florestal (Reducing Emissions from Deforestation and Forest Degradation - REED), que é um sistema de compensação para países que se comprometem com a conservação de suas florestas ${ }^{146}$.

O Acordo de Paris, igualmente celebrado no âmbito da Convenção Quadro das Nações Unidas sobre Mudança Climática, entrou em vigor em 4 de novembro de 2016. Em março de 2019, contava com 185 partes $^{147}$. Seus principais objetivos, como declarado no art. $2^{\underline{o}}$ do Acordo, são: (a) conter a elevação da temperatura média global, mantendo-a dentro de certos limites; (b) aumentar a capacidade de adaptação aos impactos adversos das mudanças climáticas; e (c) promover fluxos financeiros que realizem os dois objetivos acima ${ }^{148}$. Diferentemente do Protocolo de Kyoto, que fixou limites vinculantes de emissão, o Acordo de Paris procurou trabalhar sobre bases mais consensuais, prevendo que cada país apresentará, voluntariamente, sua "contribuição nacionalmente determinada". Por essa via, comunicam os esforços "ambiciosos" e progressivos que estarão realizando para a consecução dos objetivos previstos ${ }^{149}$. O Acordo não distingue entre os papéis dos

144 Sobre o funcionamento do sistema, v. European Comission (2019?).

145 United Nations (2019?d). Por exemplo: investe-se em um projeto de eletrificação rural utilizando painéis solares adquirindo-se créditos para abater dos limites impostos pelas obrigações assumidas, nos termos do protocolo. (UNITED NATIONS, 2019?c).

146 United Nations (2019?e). O programa tem por objetivo reduzir as emissões florestais e aumentar os estoques de carbono nas florestas, bem como contribuir para o desenvolvimento nacional sustentável.

147 United Nations (2019?f).

$148 \mathrm{O}$ art. 2, 1 do Acordo de Paris tem a seguinte redação: “O presente Acordo, no reforço da implementação da Convenção, incluindo seu objetivo, visa a fortalecer a resposta global à ameaça das mudanças climáticas, no contexto do desenvolvimento sustentável e os esforços para erradicar a pobreza, incluindo: (a) Manter o aumento da temperatura média global bem abaixo dos $2{ }^{\circ} \mathrm{C}$ acima dos níveis pré-industriais e buscar esforços para limitar o aumento da temperatura a $1,5^{\circ} \mathrm{C}$ acima dos níveis pré-industriais, reconhecendo que isso reduziria significativamente os riscos e impactos das mudanças climáticas; (b) Aumentar a capacidade de adaptar-se aos impactos adversos das mudanças climáticas e fomentar a resiliência ao clima e o desenvolvimento de baixas emissões de gases de efeito estufa, de uma forma que não ameace a produção de alimentos; (c) Promover fluxos financeiros consistentes com um caminho de baixas emissões de gases de efeito estufa e de desenvolvimento resiliente ao clima".

149 Por exemplo, de acordo com a página oficial do Ministério do Meio Ambiente do Brasil, o compromisso do país foi o seguinte: "A NDC do Brasil comprometeu-se a reduzir as emissões de gases de efeito estufa em 37\% abaixo dos níveis de 2005, em 2025, com uma contribuição indicativa subsequente de reduzir as emissões de gases de efeito estufa em 43\% abaixo dos níveis de 2005, em 2030. Para isso, o país se comprometeu a aumentar a participação de bioenergia sustentável na 
países desenvolvidos e em desenvolvimento, como fazia o Protocolo de Kyoto. A implementação do Acordo será avaliada a cada 5 anos, estando a primeira avaliação prevista para 2023. Os dois conceitos centrais aqui são os de mitigação e adapatação. Mitigação identifica as ações para reduzir a emissão de gases estufa e para aumentar a absorção de carbono da atmosfera (carbono sinks). Adaptação compreende as medidas para responder, aumentar a resiliência e reduzir a vulnerabilidade aos impactos das mudanças climáticas.

A destruição de florestas, embora tenha sofrido redução nos últimos tempos, continua a ser um problema ambiental dramático, por motivos diversos. De acordo com a FAO (Organização das Nações Unidas para Agricultura e Alimentação), cerca de 7,3 milhões de hectares de florestas, equivalentes ao tamanho do Panamá, são perdidas anualmente ${ }^{150}$. Entre 1970 e 2013, foi desmatada uma área da Amazônia equivalente ao território de duas Alemanhas. A se prosseguir nos níveis atuais de desmatamento, as florestas tropicais podem desaparecer nos próximos 100 anos $^{151}$. As causas são muitas, com destaque para a agricultura, pecuária, exploração de madeira, garimpo e expansão urbana. As consequências são graves e afetam a subsistência de inúmeras espécies, os ciclos da água, a erosão do solo e o modo de vida de populações nativas. O impacto é especialmente crítico sobre a emissão de gases estufa e o aquecimento global, já que florestas tropicais são responsáveis por aproximadamente $1 / 4$ da mitigação climática objetivada pelo Acordo de Paris ${ }^{152}$. Isso se deve à sua capacidade de absorver o dióxido de carbono da atmosfera, durante a fotossíntese, num processo conhecido como sequestro de carbono. Inversamente, a derrubada de florestas libera na atmosfera o carbono que nela estava armazenado.

Como dito acima, o regime da ONU para a mudança climática assenta-se sobre três pilares: a Convenção Quadro, o Protocolo de Kyoto e o Acordo de Paris. A propósito, o Acordo de Paris é amplamente reconhecido como um avanço significativo. A dura realidade, porém, segundo estudiosos, é que os países têm feito promessas que não serão capazes de honrar ${ }^{153}$. É preciso lembrar que, na lógica do Acordo, os países têm a flexibilidade de fixar os seus próprios compromissos, inexistindo mecanismos coercitivos de cumprimento. Nesse contexto, dois são os problemas que se detectam: as metas de redução de emissões não serão alcançadas e, ademais, têm se revelado insuficientes. O quadro geral é agravado pela decisão do Presidente Donald Trump, anunciada em 1ํ de junho de 2017, de retirar os Estados Unidos do Acordo de Paris, o que, todavia, nos termos do seu art. 28,

sua matriz energética para aproximadamente $18 \%$ até 2030 , restaurar e reflorestar 12 milhões de hectares de florestas, bem como alcançar uma participação estimada de $45 \%$ de energias renováveis na composição da matriz energética em 2030". (BRASIL, 2019).

${ }^{150}$ Fao (2016, p. 88).

${ }^{151}$ Vidal (2017).

${ }^{152}$ Gibbs, Harris e Seymour (2018).

153 Victor et al. (2017, p. 25). 
somente poderá se dar em 4 de novembro de 2022, um dia após as eleições presidenciais. Além do problema das emissões propriamente ditas, os mecanismos de financiamento como ETS e CDM estiveram envoltos em acusações de corrupção. O REED tampouco foi capaz de impedir a continuidade de desmatamentos, sem reflorestamento compensatório.

No plano doméstico, a maior parte dos países que promulgaram ou reformaram suas Constituições após a Segunda Guerra Mundial incluíram nos seus textos normas relativas à proteção ambiental ${ }^{154}$. No plano infraconstitucional, países como Brasil, México e Reino Unido aprovaram leis voltadas para a questão climática. Estados Unidos, Indonésia e Rússia adotaram medidas executivas, ao passo que Alemanha e África do Sul guiaram-se por documentos estratégicos definidores de políticas públicas ${ }^{155}$. Na União Europeia foram adotados limites rígidos nas emissões de carbono e metas para o aumento da energia renovável e da "energia eficiente"156. Também no plano judicial, uma quantidade expressiva de ações foi ajuizada mundo afora ${ }^{157}$. Merece destaque, em primeiro lugar, a importante Opinião Consultiva 23/17, da Corte Interamericana de Direitos Humanos, fazendo a correlação entre a proteção do meio ambiente e outros direitos humanos, e ditando deveres de proteção por parte dos Estados-membros ${ }^{158}$. Nos Estados Unidos, a Suprema Corte assentou, em Massachusetts v. EPA, julgado em 2007, que a Environmental Protection Agency tinha competência para regular emissões de gases estufa. Também na Holanda, decisão em ação judicial determinou que o governo reduzisse as emissões a $25 \%$ abaixo dos níveis de 1990, considerando insuficiente a redução de $17 \%$ proposta ${ }^{159}$. Ações semelhantes foram instauradas na Noruega, Áustria, Suíça e Suécia ${ }^{160}$. Merece referência o fato de que a China - que junto com os Estados Unidos é responsável por metade das emissões globais de gases estufa - mudou radicalmente o seu discurso a partir de 2014, tendo declarado "guerra à poluição". E desde o acordo de Paris, vem de fato reduzindo suas emissões e investindo em energia renovável ${ }^{161}$.

Está prevista para 2023 uma avaliação geral dos resultados obtidos com o Acordo de Paris. Há poucas dúvidas de que serão necessários esforços bem ampliados para que se atinjam as metas propostas. Nada em relação a esse tema é simples, a começar pelas tensões que ele gera no âmbito da própria ideia de

\footnotetext{
${ }^{154}$ May e Daly (2014, p. 60).

155 Averchenkova, Fankhauser e Nachmany (2017, p. 14).

156 Percival (2018, p. 608).

157 Um total de 884 casos haviam sido ajuizados em 24 países até março de 2017, de acordo com o

Programa Ambiental das Nações Unidas (United Nations Environment Programme). A maioria deles (654) foi nos Estados Unidos; 80 na Austrália, 49 no Reino Unido e 40 perante a Corte Europeia de Justiça. V. United Nations (2019?g, p. 10).

${ }^{158}$ CIDH (2017). Sobre o tema, v. Guanipa e Viedma (2018) e Duyck e Jodoin (2018).

${ }^{159}$ Urgenda Foundation v. Kingdom of the Netherlands (2015).

160 V. United Nations (2019?g, p. 15).

${ }^{161}$ Percival (2018, p. 620-622).
} 
democracia. Isso porque os ciclos eleitorais de curto prazo não favorecem decisões que mirem um horizonte de tempo mais largo. Além disso, a maioria das pessoas que serão afetadas pela mudança climática não tem voz nem voto, ou por serem muito jovens ou por sequer haverem nascido. Some-se a isso o fato de que questões técnicas e científicas intrincadas raramente atraem mobilização popular ${ }^{162}$. Por fim, por ser um problema global, não comporta soluções estritamente nacionais, o que faz com que alguns políticos nacionalistas prefiram acreditar que o problema não existe ${ }^{163}$. Diante desse quadro, o equacionamento e solução das questões afetas ao aquecimento global exigem conscientização e engajamento dos cidadãos, empresas e governos, por implicar mudanças econômicas e comportamentais profundas, que vão desde o modo como as pessoas se deslocam até como se alimentam. O que está em jogo aqui é uma questão de justiça intergeracional, para não entregarmos um planeta degradado para a posteridade. Já há mesmo quem especule acerca da necessidade de colonização do espaço, em busca de outros habitats ${ }^{164}$.

\section{CONClUSÃo}

Um balanço do século XX permite extrair algumas lições importantes. A primeira é que as conquistas civilizatórias são sempre parciais e é preciso lutar para preservá-las. Ainda que a democracia constitucional tenha sido a ideologia vitoriosa ao final do século, a história não acabou e ameaças autoritárias espreitam em muitos lugares do planeta. A segunda lição está na constatação de que, apesar das guerras, genocídios e crises diversas, os valores iluministas - razão, ciência, humanismo e progresso - avançaram. É certo que não na velocidade desejada, mas é inegável que há no mundo menos desnutrição, menos pobreza, maior acesso à educação e à saúde e maior reconhecimento de direitos, em especial às minorias historicamente estigmatizadas. Por fim, a terceira lição é a de que instituições importam. A pobreza e o atraso não são irreversíveis. A criação de instituições políticas e econômicas inclusivas pode ocorrer a qualquer tempo e mudar o rumo da história das nações.

O século XXI tem sido o cenário de transformações profundas e diferentes aflições para a humanidade. A Revolução Digital e os prospectos da Quarta Revolução Industrial, integrando o físico e o virtual, o humano e o mecânico, descortinam um mundo de promessas, desafios e riscos. A democracia vive um momento de recessão em vários rincões do planeta, exibindo fadiga de materiais e clamando por novos desenhos institucionais. E o aquecimento global, uma das questões mais dramáticas do nosso tempo, convive com o desconhecimento, o ceticismo e o uso abusivo dos recursos comuns, que impedem o desenvolvimento sustentável e comprometem o futuro das próximas gerações. Desemprego em

162 Sobre as relações entre democracia e mudança climática, v. Ward (2012).

163 V. Harari (2018, p. 121).

${ }^{164}$ Hawking (2018, p. 151; 210). V. The Economist (2019?a, p. 09; 2019?b, p. 50 et seq.). 
massa, autoritarismo e degradação ambiental constituem temores reais que demandam reflexão e atitudes.

O Direito, em geral, e o direito público, em particular, em diversas partes do mundo e em diferentes níveis, tem procurado estruturar instituições políticas e econômicas inclusivas, fixar parâmetros para as políticas públicas e disciplinar comportamentos individuais e estatais com o fim de lidar com as inovações, disrupções e ameaças dos novos tempos. Ao longo do presente ensaio, foram apontados inúmeros tratados, leis e regulações, bem como cogitadas medidas de lege ferenda, para o fim de (i) neutralizar efeitos colaterais negativos da Revolução Digital e seus desdobramentos; (ii) reforçar o sentimento democrático e superar disfunções como desigualdade e corrupção; e (iii) enfrentar de maneira efetiva o fenômeno da mudança climática. A verdade insuperável é que a velocidade, extensão e profundidade das transformações do mundo contemporâneo testam os limites e as possibilidades da atuação normativa do Estado e de organismos internacionais. $\mathrm{O}$ direito não pode tudo. É preciso que o avanço civilizatório e a elevação ética da sociedade venham em seu socorro.

Em um cenário repleto de assimetrias entre os países, marcado pela globalização, transnacionalidade dos problemas e extraterritorialidade das soluções, o direito público vive um momento existencial importante e encontra-se em busca de novos horizontes. O século XIX foi o do direito privado - do proprietário e do contratante. $\mathrm{O}$ século $X X$ assistiu à ascensão do direito público, do Estado social e da expansão da jurisdição constitucional. O século XXI convive com as demandas de uma sociedade global, que exige, em relação a temas específicos, um direito igualmente global. Não se trata de uma opção filosófica ou doutrinária, mas de uma inevitabilidade: as redes sociais via internet, o monóxido de carbono e as campanhas de desestabilização da democracia não respeitam fronteiras ou soberanias.

Em suma: processos históricos complexos como os que estamos vivendo não são lineares. Avanços civilizatórios decisivos misturam-se com riscos dramáticos, combinando medo e esperança. O futuro é imprevisível, não há roteiros prétraçados e, por isso mesmo, é preciso ter objetivos que nos inspirem e motivem. Subjacentes às ideias deste artigo estão alguns deles: (i) sobrevivência da humanidade (a distopia climática destruiria a vida na Terra); (ii) paz entre as nações (uma guerra nuclear poderia representar o fim da condição humana); (iii) preservação da democracia (soberania popular, liberdade e igualdade, dentro de um Estado de direito, são algumas das grandes conquistas da civilização); (iv) desenvolvimento sustentável (a preservação e renovação dos recursos é uma questão de justiça intergeracional); (v) busca de igualdade de oportunidades para as pessoas e para as nações (pessoas e nações devem ser livres, iguais e ter acesso aos frutos do progresso); e (vi) redes de proteção social para aqueles que ficaram à margem e de mecanismos de ajuda para os países que se atrasaram (a solidariedade com pessoas e países é um dever moral de todos). Por fim, num mundo em que já se fala em derrotar a morte e colonizar o espaço, a única bússola segura são os 
valores perenes compartilhados desde a antiguidade, entre os quais: bem, justiça e respeito ao próximo, como pressupostos da emancipação das pessoas e da proteção da dignidade humana.

\section{REFERÊNCIAS}

ACEMOGLU, Daron. Why universal basic income is a bad idea. Project Syndicate, 7 jun. 2019.

ACEMOGLU, Daron; ROBINSON, James A. Why nations fail: the origins of power, prosperity and poverty. Londres: Profile Books, 2013.

ACEMOGLU, Daron; ROBINSON, James A.. The rise and decline of general laws of capitalism. Journal of Economic Perspectives, n. 29, p. 3, 2015.

ACKERMAN, Bruce. The rise of world constitutionalism. Virginia Law Journal, n. 83, p. 771, 1997.

ACKERMAN, Bruce; ALSTOT, Anne; VAN PARIJIS, Philippe. Redesigning redistribution: basic income and stakeholders grants as cornerstones for an egalitarian capitalism. London \& New York: Verso, 2006.

ACKERMAN, Bruce; FISHKIN, James S.. Deliberation Day. The Journal of Political Philosophy, n. 10, p. 129, 2002.

ALLEGRETTI, Giovanni; DIAS, Nelson; ANTUNES, Sofia. Transformar o território promovendo a cidadania: metodologia em evolução nos orçamentos participativos de Lisboa e Cascais. Repositório do Conhecimento do IPEA, 2016. Disponível em: <http://repositorio.ipea.gov.br/handle/11058/6858>. Acesso em: 9 jun. 2019.

AUSTRALIAN GOVERNMENT. Greenhouse Effect. Department of the Environment and Energy. [2019?]. Disponível em:

$<$ http://www.environment.gov.au/climate-change/climate-science-data/climatescience/greenhouse-effect>. Acesso em: 17 mar. 2019.

AVERCHENKOVA, Alina; FANKHAUSER, Sam; NACHMANY, Michal. Trends in Climate Change Legislation. Northampton, MA: Edward Elgar, 2017. 
BARROSO, Luís Roberto. Constitucionalismo democrático: a ideologia vitoriosa do século XX. Ribeirão Preto: Migalhas, 2019.

BARROZO, Paulo. Law in time: jurisprudence for legal history. 2019. p. 9. Mimeografado.

BRANDEIS, Louis. The right of privacy, Harvard Law Review, n. 4, p. 193, 1890.

BRASIL. Acordo de Paris. Ministério do Meio Ambiente. [2019]. Disponível em: <https://www.mma.gov.br/clima/convencao-das-nacoes-unidas/acordo-de-paris>. Acesso em: 20 ago. 2019.

BRETEAU, Pierre. Comment le réchauffement climatique se ressent-ils dans votre ville?. [2018?]. Le Monde, 8 set. 2018.

BUSINESS DICTIONARY. Transaction costs. [2019?]. Disponível em: $<$ http://www.businessdictionary.com/definition/transaction-cost.html >. Acesso em: 14 jul. 2019.

CANZIAN, Fernando. Em 40 anos, metade dos EUA ganhou só US\$ 200 a mais. Folha de São Paulo, 29 jul. 2019.

CASTELLS, Manuel. Ruptura: a crise da democracia liberal. Rio de Janeiro: Zahar, 2018.

CAVALLAZZI, Vanessa Wendhausen. e-Democracia deliberativa: a deliberação social digital e a legitimidade democrática das escolhas orçamentárias para a implementação de direitos sociais, 2019. Dissertação (Mestrado em Direito), Centro Universitário de Brasília, Brasília, 2019.

CERULUS, Laurens. Sigmar Gabriel: 'Merkel's austerity is driving EU to brink of collapse'. Politico, 8 jan. 2017. Disponível em:

$<$ https://www.politico.eu/article/sigmar-gabriel-angela-merkel-austerity-isdriving-eu-to-brink-of-collapse/>. Acesso em: 20 ago. 2019.

CIDH. Opinión Consultiva OC-23/17. 2017. Disponível em: <http://www.corteidh.or.cr/docs/opiniones/seriea_23_esp.pdf>. Acesso em: 18 abr. 2019.

COASE, Ronald. The nature of the firm. Economica, v. 16, p. 386-405, 1937. 
COHEN, Joshua. Deliberation and democratic legitimacy. In: BOHMAN, James; REHG, William (eds.). Deliberative Democracy: essays on reasons on reasons and politics. Cambridge: The MIT Press, 1997.

COHEN, Stewart J.; WADDELL, Melissa W. Climate change in the 21st century. Montréal: McGill-Queen's University Press, 2009.

CONFESSORE, Nicholas. Cambridge Analytica and Facebook: the scandal and the fallout so far. The New York Times, 4 abr. 2018.

CONSTITUTE PROJECT. Right of privacy. [2019?]. Disponível em:

<https://www.constituteproject.org/search?lang=en\&key=privacy>. Acesso em: 4 maio 2019.

COOPER, Ryan. Why everyone is talking about Thomas Piketty's Capital in the twenty-first century. The Week, 25 mar. 2014. Disponível em:

$<$ https://theweek.com/articles/448863/why-everyone-talking-about-thomaspikettys-capital-twentyfirst-century>. Acesso em: 23 abr. 2019.

CORBETT, Julia B.; DURFEE, Jessica L.. Testing public (un)certainty of Science: media representations of global warming. Science Communication, n. 26, p. 129, 2004 .

DIAMOND, Larry. Facing up to the democratic recession. Journal of Democracy, n. 26, p. 141, 2015.

DUYCK, Sébastien; JODOIN, Sébastien; JOHL, Alyssa. Routledge handbook of human rights and climate governance. New York: Routledge, 2018.

ELSTER, Jon. (ed). Tocqueville: the Ancien Régime and the French Revolution. Trad. Arthur Goldhammer. New York: Cambridge University Press, 2011, p. 17085.

EUROPEAN COMISSION. EU Emissions Trading System (EU ETS). [2019?].

Disponível em: <https://ec.europa.eu/clima/policies/ets_en>. Acesso em: 20 ago. 2019. 
FAO. State of world's forests. Forests and agriculture: land use, challenges and opportunities. 2016, p. 88. Disponível em: http://www.fao.org/3/a-i5588e.pdf. Acesso em: 16 abr. 2019.

FISHKIN, James S.. Consulting the public through deliberative polling. Journal of Policy Analysis and Management, n. 22, p. 128, 2003.

FLAVELLE, Christopher. Climate change threatens the world's food supply, United Nations warns. The New York Times, 8 ago. 2019.

FOA, Roberto Stefan; MOUNK, Yascha. The democratic disconnect. Journal of Democracy, n. 27, 2016, p. 8.

FORD FOUNDATION. An Assessment of the Chilean Constituent Process. Observatory of the Chilean Constituent Process. 2018. Disponível em: $<$ http://redconstituyente.cl/wp-content/uploads/2018/04/An-assessment-of-theChilean-constituent-process-web.pdf>. Acesso em: 6 maio 2019.

FREEDOM HOUSE. End of century survey finds dramatic gains for democracy. [2019?]. New York, 7 dez. 1999. Disponível em:

https://freedomhouse.org/article/end-century-survey-finds-dramatic-gainsdemocracy. Acesso em: 12 ago. 2019.

FREY, Carl Benedikt; OSBORNE, Michael A. The future of employment: how susceptible are jobs to computerisation?. Oxford Martin School, University of Oxford, 17 set. 2013. Disponível em: <https://www.oxfordmartin.ox.ac.uk/ downloads/academic/The_Future_of_Employment.pdf>. Acesso em: 18 jul. 2019.

FUKUYAMA, Francis. The End of History and the Last Man. New York: Free Press, 1992.

FUKUYAMA, Francis. The end of history. The National Interest, n. 16, p. 3-18, 1989.

FUNG, Archon. Minipublics: designing institutions for effective deliberation and accountability. In: ODUGBEMI, Sina; LEE, Taeku (ed.). Accountability through Public Opinion, Washington D.C.: The World Bank, 2011, p. 183-202.

GELBSPAN, Ross. The heat is on: the high stakes battle over Earth's threatened climate. Reading, Mass: Addison-Wesley Pub, 1997. 
GIBBS, David; HARRIS, Nancy; SEYMOUR, Frances. By the numbers: the value of tropical forests in the climate change equation. World Resources Institute, 4 out. 2018. Disponível em: <https://www.wri.org/blog/2018/10/numbers-value-tropicalforests-climate-change-equation>. Acesso em: 16 abr. 2019.

GLEIZER, Marcelo. Criação Imperfeita. Rio de Janeiro: Record, 2012.

GOODWIN, Tom. The battle is for the interface with the client. Techcrunch, 03 mar. 2015. Disponível em: <https://techcrunch.com/2015/03/03/in-the-age-ofdisintermediation-the-battle-is-all-for-the-customer-interface/>. Acesso em: 30 jul. 2019.

GREENHOUSE Effect. National Geographic. Disponível em: <https://www. nationalgeographic.org/encyclopedia/greenhouse-effect/>. Acesso em 17 mar. 2019.

GUANIPA, Henry Jimenez; VIEDMA, Eduardo (coords.). Energía, cambio climático y desarollo sostenible: impacto sobre los derechos humanos. Bogotá: Fundación Heirich Böll, 2018.

GUTMANN, A.; THOMPSON, D.. Why Deliberative Democracy?. Princenton: Princeton University Press, 2004, p. 125-138.

HABERMAS, Jurgen. Direito e democracia: entre facticidade e validade. Trad. Flávio Beno Siebeneichler. Rio de Janeiro: Tempo Brasileiro, 1997.

HANSEN, James et al.. Ice melt, sea level rise and superstorms: evidence from paleoclimate data, climate modeling, and modern observations that $2^{\circ} \mathrm{C}$ global warming could be dangerous. Atmospheric, Chemestry and Physics, n. 16, p. 3761, 2016.

HARARI, Yuval Noah. 21 lessons for the $21^{\text {st }}$ century. New York: Spiegel \& Grau, 2018, p. 34 et seq.

HARARI, Yuval Noah. Homo Deus. New York: HarperCollins Publishers, 2017, p. 21.

HARARI, Yuval Noah. Sapiens: a brief history of humankind. New York: HarperCollins Publishers. 
HARDIN, Garret. Tragedy of the commons. Science, n. 162, p. 1243, 1968.

HARRISON, Kathryn; SUNDSTROM, Lisa McIntosh. Global commons, domestic decisions: the comparative politics of climate change. Cambridge, MIT Press, 2010, p. ix.

HASELL, Joe. Is income inequality rising around the world?. Our World in Data, 2018. Disponível em: <https://ourworldindata.org/income-inequality-since-1990>. Acesso em: 19 nov. 2018.

HAWKING, Stephen. Brief answers to the big questions. New York: Bantam Books, 2018.

HILL, Andrew; KHAN, Mehreen; WATERS, Richard. The global hunt to tax big tech. Financial Times, 2 nov. 2018.

HINSBERT, Hille; JONSSON, Magnus; KARLSSON, Martin. E-Participation Policy in Estonia. In: ASTROM, Joachim et al. Citizen centric e-participation: a trilateral collaboration for democratic innovation. Tallinn: Praxis Policy Center, p. 17-29, 2013. Disponível em: <http://www.diva-portal.org/smash/get/ diva2:638808/FULLTEXT01.pdf>. Acesso em: 6 maio 2019.

HOBSBAWM, Eric. Age of extremes. Londres: Penguim, 1994.

HOLMES, Stephen. How democracies perish. In: SUSTEIN, Cass (ed). Can it happen here: authoritarianism in America. New York: HarperCollins, 2018.

HUGHES, Chris. It's time to break up Facebook. The New York Times, 9 mai. 2019.

HUNTINGTON, Samuel P.. The third wave: democratization in the late twentieth century. Journal of Democracy, n. 2, p. 12, 1991.

HUQ, Aziz; GINSBURG, Tom. How to lose a constitutional democracy. UCLA Law Review, n. 65, 2018.

HUXLEY, Aldous. Brave new world. New York: Double day, 1932. 
INGLEHART, Ronald F.; NORRIS, Pippa. Trump, Brexit, and the rise of populism: economic have-nots and cultural backlash. Working Paper Series RWP16-026. Harvard University, John F. Kennedy School of Government, 2016.

INMAN, Phillip. IMF chief joins calls for big tech firms to pay more tax. The Guardian, 25 mar. 2019.

ISSACHAROFF, Samuel. Populism versus democratic governance. In: GRABER, Mark A.; LEVINSON, Sanford; TUSHNET, Mark. Constitutional democracy in crisis?. Oxford: Oxford University Press, 2018.

KAPLAN, Jerry. Artificial intelligence: what everyone needs to know. New York: Oxford University Press, 2016.

KRUGMAN, Paul. Wealth of work. The New York Times, 23 mar. 2014.

Disponível em: $<$ https://www.nytimes.com/2014/03/24/opinion/krugman-wealthover-work.html>. Acesso em: 23 abr. 2019.

LANDEMORE, Helene. Inclusive Constitution-Making: the Icelandic experiment. The Journal of Political Philosophy, n. 23, 2015.

LANGLOIS, Adèle. The global governance of human cloning: the case of UNESCO. Palgrave Communications, n. 3, p. 17019, 2017. Disponível em: $<$ https://www.nature.com/articles/palcomms201719>. Acesso em: 11 jul. 2019.

LATINOBARÓMETRO. [2019?]. Disponível em: $<$ http://www.latinobarometro.org/lat.jsp>. Acesso em: 20 ago. 2019.

LEVITSKY, Steven; ZIBLATT, Daniel. How democracies die. New York: Crown, 2018.

LINDZEN, Richard S.. There Is No 'Consensus' on Global Warming. The Wall Street Journal, 26 jun. 2006. Disponível em:

$<$ https://www.cpp.edu/ zywang/lindzen.pdf>. Acesso em: 6 jun. 2019.

LLOYD, William Forster. Two lectures on the check to population. Oxford:

Oxford University, 1833. Disponível em: <https://archive.org/stream/ twolecturesonch00lloygoog/twolecturesonch00lloygoog_djvu.txt $>$. Acesso em: 8 jun. 2019. 
LOHR, Steve. How do you govern machines that can learn? Policymakers are trying to figure that out. The New York Times, 20 jan. 2019.

MANSBRIDGE, Jane. Deliberative democracy or democratic deliberation?. In: ROSENBERG, Shawn W. (ed.). Deliberation, Participation and Democracy: can the people govern?. New York: Palgrave Macmilian, 2003.

MAY, James R.; DALY, Erin. Global Environmental constitutionalism. Cambridge: Cambridge University Press, 2014.

MCKAY, Tom. G 20 countries agree on approach to shut down big techs' tax loopholes. Gizmodo, 6 set. 2019.

MEDIUM. Equal Citizens. On Iceland's crowdsourced constitution. 14 maio 2016. Disponível em: <https://medium.com/equal-citizens/on-icelands-crowdsourcedconstitution-ad99aae75fce>. Acesso em: 6 jun. 2019.

MICHAELS, Patrick J.. Meltdown: the predictable distortion of global warming by scientists, politicians, and the media. Washington, D.C.: Cato Institute, 2004.

MILLER, Brandon; FOX, Kara. Cyclone Idai could be the deadliest tropical cyclone to hit Africa. Here's what you need to know. CNN. Disponível em: https:/edition.cnn.com/2019/03/19/weather/cyclone-idai-mozambique-factsintl/index.html. Acesso em: 20 mar. 2019.

MOORLOCK, Greg. A look inside the murky world of the illegal organ trade. Independent, 24 jul. 2018.

NASA. Global climate change. [2019?]. Disponível em:

<https://climate.nasa.gov/evidence/>. Acesso em: 17 mar. 2019.

NEATE, Rupert. Richest 1\% owns half the world's wealth, study finds. The Guardian, 14 nov. 2017.

NEW YORK STATE. What is the difference between reproductive and therapeutic cloning?.Stem Cell Science. Disponível em: <https://stemcell.ny.gov/faqs/whatdifference-between-reproductive-and-therapeutic-cloning>. Acesso em: 11 jul. 2019. 
NORDHAUS, William. The Climate Casino: risk, uncertainty, and economics for a warming world. New Haven: Yale University Press, 2013.

NORTH, Douglass C. Instituições, mudança institucional e desempenho econômico. Trad. Alexandre Morales. São Paulo: Três Estrelas, 2018.

OECD. Basic income as a policy option: technical background note illustrating costs and distributional implications for selected countries. Mai. 2017. Disponível em: https://www.oecd.org/els/soc/Basic-Income-Policy-Option-2017-BrackgroundTechnical-Note.pdf. Acesso em: 13 jul. 2019.

OLIVEIRA, Regiane. Desemprego no Brasil chega a 12,5\% e atinge 13,2 milhões de trabalhadores, diz IBGE. El País, São Paulo, 1ํ jun. 2019.

ORESKES, Naomi. The scientific consensus on climate change: how do we know we're not wrong? In: DIMENTO, Joseph F.; DOUGHMAN, Pamela (eds.). Climate Change: what it means for us, our children, and our grandchildren. Cambridge: MIT Press, 2007.

ORWELL, George. 1984. New York: Chelsea House, 2007 (a 1ae edição é de 1949).

OSTROM, Elinor. Governing the commons. New York: Cambridge University Press, 1990.

PERCIVAL, Robert V.. The climate crisis and constitutional democracy. In: GRABER, Mark A.; LEVINSON, Sanford; TUSHNET, Mark. Constitutional democracy in crisis?. Oxford: Oxford University Press, 2018, p. 608.

PETTIT, Philip. Deliberative democracy and the discursive dilemma. In: FISHKIN, James; LASLETT, Peter (eds.). Debating Deliberative Democracy. Oxford: Blackwell, 2003, p. 138-162.

PIKETTY, Thomas. Capital in the twenty first century. Londres: Belknap, 2014.

PINKER, Steven. Enlightenment now: the case for reason, science, humanism and progress. New York: Penguin, 2018. 
PINOTTI, Maria Cristina. Corrupção e estagnação econômica: Brasil e Itália. In: PINOTTI, Maria Cristina (org.), Corrupção: lava jato e mãos limpas. São Paulo: Portfolio-Penguin, 2019.

PREFEITURA DE PORTO ALEGRE. OP, 25 anos em Porto Alegre. [2019?]. Disponível em: <http://www2.portoalegre.rs.gov.br/smgl/default.php? p_secao=86>. Acesso em: 9 maio 2019.

RISSE, Mathias. Human rights and artificial inteligence. Publicum, n. 4, p. 11, 2018.

ROCKE, Anja. Framing citizen participation: participatory budgeting in France, Germany and the United Kingdom. Londres: Palgrave Macmillan, 2014.

RODRIGUES, Léo. Número de usuários da internet cresce 10 milhões em um ano no Brasil. Agência Brasil, 20 dez. 2018. Disponível em: <http://agenciabrasil.ebc. com.br/economia/noticia/2018-12/numero-de-usuarios-de-internet-cresce-10milhoes-em-um-ano-no-brasil>. Acesso em: 4 mai. 2019.

ROMM, Joseph. Is there a difference between global warming and climate change? The Years Project. Disponível em: <https://theyearsproject.com/askjoe/difference-global-warming-climate-change/>. Acesso em 4 jul. 2019.

ROSE-ACKERMAN, Susan; PALIFKA, Bonnie J.. Corruption and government: causes, consequences, and reform. 2 ed. New York: Cambridge University Press, 2016.

SCHEPPELE, Kim Lane. Autocratic legalism. The University of Chicago Law Review, n. 85, p. 545, 2018.

SCHUMPETER, Joseph. Capitalism, socialism and democracy. New York: HarperCollins, 2008 (a 1ª edição é de 1942).

SCHWAB, Klaus. The fourth industrial revolution. New York: Crown Business, 2017.

SCHWAB, Klaus. The fourth industrial revolution: what it means and how to respond. World Economic Forum, 14 jan. 2016. Disponível em: <https://www. weforum.org/agenda/2016/01/the-fourth-industrial-revolution-what-it-meansand-how-to-respond/>. Acesso em: 08 mar. 2019. 
SINGER, Fred S.; AVERY, Dennis T.. Unstoppable global warming: every 1,500 years (Updated and expanded ed.). Lanham: Rowman \& Littlefield, 2007.

STEPHEN Holmes. How democracies die. 13 mar. 2017. 1 vídeo. (86 min). Publicado pelo canal The Graduate Institute Geneva. Disponível em: <https://www.youtube.com/watch?v=nHr6Mcqq-Ek>. Acesso em: 12 jul. 2019.

SUMI, Akimasa; MIMURA, Nobuo. From climate change to global sustainability, Introduction. In: SUMI, Akimasa; MIMURA, Nobuo; MASUI, Toshihiko (eds). Climate change and global sustainability: a holistic approach. New York: United Nations University Press, 2011.

SUNSTEIN, Cass. Neither Hayek nor Habermas. Public Choice, v. 134, p. 87-95, 2008.

SUNSTEIN, Cass. The daily we. Boston Review, Summer 2001.

SUNSTEIN, Cass. The law of group polarization. The Journal of Political Philosophy, n. 10, p. 177, 2002.

THE ECONOMIST. The world's most valuable resource is no longer oil, but data. 6-12 maio 2017 (2017a).

THE ECONOMIST. Fuel of the future. 6-12 maio 2017 (2017b).

THE ECONOMIST. The next 50 years in space. 20-26 jul. 2019 (2019a).

THE ECONOMIST. Star laws. 20-26 jul. 2019 (2019b).

TRACY, Ryan. Big techs summoned to Washington for antitrust hearing. The Wall Street Journal, 9 jul. 2019.

TROTMAN, Andrew. Angela Merkel: 'Austerity makes it sound evil, I call it balancing the budget'. The Telegraph, 23 abr. 2013. Disponível em: $<$ https://www.telegraph.co.uk/finance/financialcrisis/10013814/Angela-MerkelAusterity-makes-it-sound-evil-I-call-it-balancing-the-budget.html>. Acesso em: 20 ago. 2019. 
UNITED NATIONS. The 2030 Agenda for Sustainable Development. Goal 13. [2019?a] Disponível em: <https://sustainabledevelopment.un.org/?menu=1300>. Acesso em: 20 ago. 19.

UNITED NATIONS. The intergovernmental Panel on Climate Change. [2019?b]. Disponível em: <https://www.ipcc.ch>. Acesso em: 18 mar. 2019.

UNITED NATIONS. The Clean Development Mechanism. [2019?c]. Disponível em: <https://unfccc.int/process-and-meetings/the-kyoto-protocol/mechanismsunder-the-kyoto-protocol/the-clean-development-mechanism>. Acesso em: 16 abr. 2019.

UNITED NATIONS. What is the CDM. Clean Development Mechanism. [2019?d]. Disponível em: <https://cdm.unfccc.int/about/index.html>. Acesso em: 23 jan. 2019.

UNITED NATIONS. UN-REDD Programme. [2019?e]. Disponível em: <http://www.un-redd.org/how-we-work-1>. Acesso em: 23 jan. 2019.

UNITED NATIONS. Climate Change. Paris Agreement - Status of Ratification. [2019?f]. Disponível em: <https://unfccc.int/process/the-paris-agreement/statusof-ratification>. Acesso em: 16 abr. 2019.

UNITED Nations Environment Programme. The Status of Climate Change Litigation. [2019?g]. Disponível em: $<$ http://wedocs.unep.org/bitstream/handle/20.500.11822/20767/climate-changelitigation.pdf?sequence=1\&isAllowed=y>. Acesso em: 18 abr. 2019.

VERGARA, Walter; SCHOLZ, Sebastian M. (eds.). Assessment of the Risk of Amazon Dieback. Washington, D.C.: The World Bank, 2011.

VICTOR, David G. et al.. Prove Paris was more than paper promises. Nature, n. 548, p. 25, 3 ago. 2017.

VIDAL, John. We are destroying rainforests so quickly they may be gone in a 100 years. The Guardian, 23 jan. 2017. Disponível em: <https:/www.theguardian.com/ global-development-professionals-network/2017/jan/23/destroying-rainforestsquickly-gone-100-years-deforestation>. Acesso em: 16 abr. 2019. 
VISHWANATH, Arun. The internet is already being weaponized. The U.S. cyberattack on Iran won't help. The Washington Post, 9 jul. 2019.

WARD, Halina. The future of democracy in the face of climate change: how might democracy and participatory decision-making have evolved to cope with the challenges of climate change by the years 2050 and 2100?. Foundation for Democracy and Sustainable Development, 2012. Disponível em: <http://www. fdsd.org/site/wp-content/uploads/2014/11/Democracy-and-climate-changescenarios-final-with-foreword.pdf>. Acesso em: 17 jul. 2019.

WATERS, Richard; BOND, Shannon; MURPHY, Hannah. Global regulators' net tightens around big tech. Financial Times, 5 jun. 2019.

WIKIPEDIA. Organ Trade. [2019?]. Disponível em: $<$ https://en.wikipedia.org/wiki/Organ_trade>. Acesso em: 24 jul. 2018.

WINSTON, Patrick Henry. Artificial intelligence desmystified. Mimeografado. Minuta de 30 set. 2018, gentilmente enviada pelo autor.

ZAKARIA, Fareed. The rise of illiberal democracies. Foreign Affairs, n. 76, p. 22, 1997. 